\title{
The Abandonment Defense to Criminal Attempt and Other Problems of Temporal Individuation
}

\author{
Paul R. Hoeber $\dagger$
}

Criminal prohibitions have temporal dimensions in the sense that, given the definition of any crime, we may refer to later occurrences as "post-crime" conduct or events. In relation to the crime of theft, for example, the return of stolen property is a post-crime event. In relation to the crime of attempt, abandonment is a post-crime event. Criminally prohibited states of affairs are thus, I shall say, temporally individuated.

This feature of criminal prohibitions bears importantly on criminalization decisions. For in deciding what states of affairs to prohibit, we necessarily have choices to make in defining the temporal dimensions of hability. When these choices are disputed-when claims are urged for the relevance of particular post-crime conduct or events-we face problems of temporal individuation. The dispute over the abandonment defense to attempt presents a problem of temporal individuation im the decision to criminalize attempts.

In this Article, I propose a general form of argument for use in criminalization decisions that raise problems of temporal individuation. By applying that form of argument, I intend to advance a satisfactory argument, heretofore lacking, im support of the abandonment defense. And since the rationale that justifies prohibiting attempts determines whether the defense should be recognized, I also intend to establish an adequate justification of attempt hability.

I

The Form of Argument and the Abandonment DEFENSE

\section{A. Temporal Individuation and Criminalization Decisions}

The traditional common law view is that abandonment caimot be a defense to attempt. This view is usually expressed in pronouncements

$\dagger$ B.A. 1966, J.D. 1970, University of California, Berkeley. Thanks for their help to my friends Meir Dan-Cohen and Willie Fletcher. 
that an attempt, like any other crime, is "complete" and that later abandonment can no more affect a defendant's attempt liability than later repentance or remorse can affect a defendant's liability for any other crime. ${ }^{1}$

This attitude towards the abandonment defense exhibits a fundamental misconception about criminalization decisions. The crime of attempt, like any other crime, is complete when we say it is. The temporal dimensions of attempt habihity are defined differently depending on whether the law recognizes a defense for those who abandon their efforts after engaging in conduct otherwise constituting an attempt. Thus, to decide whether defendants who abandon have a defense is to decide (to that extent) what states of affairs the crime prohibits.

Let me put the general problem in schematic terms. Suppose that doing act $B$ is a crime, that some conduct or event $P$ may or may not occur after the doing of $B$, and that the question arises whether the later occurrence of $P$ should be a defense (the $P$ defense) to the crime of $B$. This criminalization decision poses the following alternatives. Refusing to recognize the $P$ defense inakes $B$ a crime regardless of whether $P$ later occurs. On the other hand, recognizing the $P$ defense teinporally individuates the crime in a different way: $B$ is a crime when $P$ does not later occur ( $B$-and-non $P$ ), but not when $P$ does later occur $(B$-and- $P$ ).

To resolve such problems we must ensure that prohibited states of

1. The following examples are representative: M. BASSIOUNI, SUBSTANTIVE CRIMINAL LAW 205 (1978) (" $[N]$ o subsequent repentance, change of mind, or abstention from further acts can erase responsibility for the acts of attempt already committed."); $1 \mathrm{~J}$. BISHOP, CRIMINAL LAW $\S 732$, at 523 (9th ed. 1923) ("A crime, once committed, ... cannot be obliterated by repentance. Therefore if ... [the defendant's] act amounts to an indictable attempt, it does not cease to be such though he voluntarily abandons the evil purpose."(footnotes omitted)); W. CLARK, HANDBOOK OF CRIMINAL LAW 150 (3d ed. 1915) ("[H] e cannot purge himself by abandoning [the attempt]. To say otherwise would be to allow one to escape punishment by repenting after the crime has been committed."(footnote omitted)); A. MeWETt \& M. MANNing, Criminal LAW 178 (2d ed. 1985) ("Once the attempt is completed, it makes no difference, any more than in any other offence whether the accused ... abandons the attempt. He cannot undo the completed offence ...."); G. WiLliams, CRim1Nal LAW: The General PART \& 199, at 620 (2d ed. 1961) ("Voluntary abandonment of the project does not, it seems, expunge existing guilt."(footnote omitted)); Beale, Criminal Attempts, 16 HARV. L. REV. 491, 506 (1903) ("II]t is immaterial that the defendant may voluntarily desist from his attempt before it succeeds.... [S]ubsequent repentance and withdrawal from the crime ... could not purge his guilt."(footnote omitted)); Perkins, Criminal Attempt and Related Problems, 2 UCLA L. REV. 319, 354 (1955) ("A criminal attempt is a 'complete offense' in the sense that one ... can no more wipe out his criminal guilt by an abandonment of his plan than a thief can obliterate a larceny by a restoration of the stolen chattel."(footnote omitted)); Sayre, Criminal Attempts, 41 HARV. L. REv. 821, 847 (1928) ("Once the defendant's acts have gone far enough to make him liable for a criminal attempt, no subsequent repentance or change of mind . . can possibly wipe away liability for the crime already committed. . . . Present virtue never wipes away past crimes."(footnote omitted)); Skilton, The Requisite Act in a Criminal Attempt, 3 U. PITr. L. REv. 308, 310 (1937) ("[N]othing that the defendant can do . . can remove the fact that the defendant has already committed a criminal attempt."). For judicial statements of the common law view, see infra note 13. 
affairs are temporally individuated in ways that correspond to our reasons for the prohibitions. Accordingly, we should decide whether to recognize the $P$ defense to the crime of $B$ by, first, establishing the rationale that justifies hability for $B$-and-non $P$ and then, second, determining wliether that rationale similarly justifies hability for $B$-and- $P$. If it does not, then we are justified in prohibitmg only $B$-and-non $P$, and we shonld recognize the $P$ defense.

The assumption underlymg this form of argument is that criminalization decisions require justification. For the question whether a criminal prohibition is justified includes the question whether the prohibited state of affairs is properly individuated in time. Hence, whatever conduct we (propose to) prohibit, we inust be able to ineet the claim that we should define the dimensions of liability differently because of some postcrime conduct or event. The form of arguinent outlined above enables us to ensure that in relation to such conduct or events criminal prohibitions impose only justified liability.

In Parts II and III, I apply this form of arguinent to the crime of attempt and the post-crime event of abandonment. As the argument inust estabhish the rationale that justifies atteinpt liability, I show both why the law should prohibit atteinpts and why it should recognize the abandonment defense. Moreover, if the general form of argument is sound, it should be used wlienever probleins of temporal individuation arise. In Part IV, therefore, I illustrate its application to other crimes and other post-crime conduct or events. Together with iny arguinent for the abandoninent defense, these illustrations deinonstrate how to proceed in order to justify the temporal choices made in criminalization decisions.

\section{B. History and Current Status of the Abandonment Defense}

Altliough the idea of an abandonınent defense to attempt apparently originated in inedieval Italy, ${ }^{2}$ its inodern influence dates froin the attempt provision in the French Penal Code of 1810. Tliat provision, widely copied in nineteenth-century penal codes, ${ }^{3}$ prohibits conduct that fails "only because of circuinstances independent of the perpetrator's will," thus excluding abandonment cases froin atteinpt liability. The German Penal Code of 1871 , in a separate provision, exempted from punishment one who "abandoned the completion of the intended act, not

2. See Meehan, The Trying Problem of Criminal Attempt-Historical Perspectives, $14 \mathrm{U}$. BRIT. COLUM. L. REV. 137, 144 (1979).

3. See H. Sanford, The Different Systems of Penal Codes in Europe $61,91,96,118$, 122 (1854) (noting French attempt provision copied in codes of Prussia, Baden, Austria, Belgium, and Portugal).

4. CODE PENAL art. 2 (Fr.) (“des circonstances indépendantes de la volonté de son auteur"), translated in The French Penal Code 15 (J. Moreau \& G. Mueller trans. 1960). 
having been prevented from such completion by circuinstances independent of his will." By 1883, Stephen was able to say that "French law, and that of most other countries, takes no notice of an attempt to cominit a crime from which the offender voluntarily desists."

Stephen's observation remains true today. Many countries follow the French formulation, defining attempt to include only cases where failure results from circumstances independent of the perpetrator's will, ${ }^{7}$ and many others follow the German example of providing separately for a defense, though now such provisions declare that those who "voluntarily" abandon shall not be punished for attempt. ${ }^{8}$ The Anglo-American

5. StrafGeseTzBuch [STGB] art. 46(1) (W. Ger.) (repealed 1975), translated in THE German Penal CODE 37-38 (G. Mueller \& T. Buergenthal trans. 1961). For last-act attempts, this provision required that the perpetrator prevent completion of the crime before discovery of the attempt. Id. art. 46(2); see Schwenk, Criminal Codification and General Principles of Criminal Law in Germany and the United States-A Comparative Study, 15 TUL. L. REv. 541, 561 (1941).

6. 2 J.F. Stephen, A History of the CRiminal LaW of ENGLANd 226 (1883). A few nineteenth-century penal codes provided only a reduced penalty for prevention of the crime after the last act. See CoDiCE PENALE [C.P.] arts. 61-62 (Italy) (repealed 1930); C6́digo PENAL [C.P.] arts. 10-11 (Port.) (repealed 1982).

7. Such provisions appear in COde PÉnal art. 30 (Algeria); Code PÉNAl art. 51 (Belg.); Codigo Penal art. 24 (Costa Rica); Codigo Penal art. 2 (Dom. Rep.); Code pénal art. 45 (Egypt); Codigo Penal art. 12 (Mex.); Code Pénal art. 114 (Morocco); Wetboek Van Strafrecht art. 45(1) (Neth.), translated in J. Diening, ON REAsonable Liability: A Comparison of Dutch and Canadian Law Regarding tite Limits of Criminal Liability 101 (1982); Codigo Penal art. 6 (Niear.); Revised Penal Code art. 6 (Phil.); Codigo Penal art. 3 (Spain); Code Pénal art. 4 (Zaire).

8. Such provisions appear in StrafgesetzBuch [STGB] art. 16(1) (Aus.); Strafgesetzbuch art. 18(3) (Bulg.); Codigo Penal art. 13(1) (Cuba); The Danish Criminal CODE $\S 22$ (E. Giersing trans. 1958); STRAFGesetzBuch art. 21(5) (E. Ger.); CoDE PÉNAL ch. IV, $\S 2$ (Fin.); Act IV of 1978 the Criminal Code of the Hungarian People's Republic $\S 17(3)$, translated in 1980 Hungarian L. Rev. 25, 28; Norwegian Penal Code $§ 50$ (H. Schjoldager trans. 1961); Codigo Penal art. 95 (Peru); Penal Code of the Polish People's RePUblic $\S 13(1)$ (W. Kenney \& T. Sadowski trans. 1973); C.P. art. 24(1) (Port.); PeNal Code of THE Romanian Socialist RePUblic $\$ 22$ (S-M V. Kleckner trans. 1976); THE PENal Code of SWEDEN ch. 23, § 3 (T. Sellin trans. 1984); STGB art. 24(1) (W. Ger.).

Three other variations are current:

(1) For codes that define attempt as failure due to independent circumstances and also provide separately for an abandonment defense, see Codigo PENAL arts. $42-43$ (Argen.), translated in THE ARgentine Penal Code 31 (E. Gonzalez-Lopez trans. 1963); Codigo Penal arts. 12(II), 13 (Braz.); Codigo Penal arts. 15-16 (Colom.), translated in The Columbian Penal Code 19-20 (P. Eder trans. 1967); CRIMINAL Code OF MALTA $\S 42(1)$; CRIMINAL Code RSFSR arts. 15-16, translated in THE SOVIET CODES OF LAW 60 (W. Simons ed. 1980).

(2) For codes providing that abandonment before the last act precludes punishment, while preventing commission of the crime after the last act only mitigates the penalty, sec Codigo PENAL art. 16 (Ecuador); THE GREek PeNAl CODE art. 44 (N. Lolis trans. 1973); C.P. art. 56 (Italy), translated in The Italian Penal Code 19 (E. Wise trans. 1978); The Penal Code of the Somali Democratic Republic art. 18 (M. Ganzglass ed. 1971); THE Turkish Criminal Code arts. 61-62 (O. Sepici \& M. Ovacik trans. 1965).

(3) For codes providing that abandonment is the basis for remitting or reducing the penalty for attempt, see Criminal Code of the People's Republic of China art. 21 (C. Kim trans. 1982); Penal Code of EThiopia art. 28, translated in S. Lowenstein, Materials on Comparative CRIminal LaW as Based upon the Penal Codes of Ethiopia AND Switzerland 118 (1965); 
legal world, however, with a judicially created crime of attempt, presents a strikingly different picture.

For the common law, the question was whether an individual who had already committed an attempt could avoid hability by abandonment. Although the Enghish courts never gave the question thorough consideration, ${ }^{9}$ Stephen's draft criminal code in 1878 and the ensumg Commissioners' Code in 1879 exphicitly answered in the negative, ${ }^{10}$ and it is now well settled that abandonment is irrelevant to attempt liability at common law. ${ }^{11}$ Umited States judicial decisions follow this tradition. Despite occasional suggestions to the contrary, ${ }^{12}$ American courts have consist-

Greenland Criminal Code § 88(6) (V. Goldschmidt intro. 1970); KeIHoo (Penal Code), Law No. 45 of 1907, art. 43 (Japan), translated in PENAL CODE OF JAPAN 11 (rev. ed. 1973); KOREAN CRIMINal Code art. 26 (P. Ryu trans. 1960); CoDE PÉNAL suISSE arts. 21-22 (Switz.), translated in 30 J. Crim. L. \& Criminology 1, 22 (Supp. 1939).

9. The attempt cases cited most frequently in this connection are Haughton v. Smith, 1975 App. Cas. 476, 493; Regina v. Lankford, 1959 CRIM. L. REv. 209 (Crim. App.); Regina v. Taylor, 175 Eng. Rep. 831 (1859). For commentary on these cases, see E. MEEHAN, THE LAw OF Criminal Attempt 216-18 (1984); Stuart, The Actus Reus in Attempts, 1970 Crim. L. REv. 505, 519-20.

10. See Bill 178, Criminal Code (Indictable Offences) Bill $\S 32$ (1878); Report of the Royal Comm'n Appointed to Consider the Law Relating to Indictable Offences, Draft Code $\$ 74$ (1879); see also J.F. STEPHEN, A Digest of THE Criminal LAw art. 49, at 30 (1877) (rejecting abandonment defense). Another English codifier, however, provided for mitigation of the penalty in abandonment cases. R.S. Wright, Drafts of a Criminal Code and a Code of Criminal Procedure for THE ISLAND OF JAMAiCA WITH AN EXPLANATORY MEMORANDUM § 30(ii) \& illustration (1877); see Friedland, R.S. Wright's Model Criminal Code: A Forgotten Chapter in the History of the Criminal Law, 1 Oxford J. Legal STud. 307, 332 (1981).

Somewhat later, the attempt provision in the Queensland Criminal Code specifically rejected the abandonment defense, Criminal Code Act, $1899 \S 4,3$ QUEENSL. PUB. ACTS (1964), though it did mitigate the penalty, id. $\S 538$. See R. O'REgan, Criminal Attempts in the Griffith Code, in ESSAYS ON THE AUSTRALIAN CRIMINAL CODE 137, 147 (1979); Herlihy, Attempts and Impossibility Under the Queensland Criminal Code, 11 U. QueENS. L.J. 160, 166-67 (1980). The Code became influential in the British Commonwealth, and a number of codes mirror its attempt provision (with or without its mitigation provision), including Crimmal Code Act, $1913 \S \S 4,555$, W. AUSTL. REPR. ACTS; Criminal Code $\S 366$, STAT. Laws of CYPRus ch. 154 (rev. ed. 1959); Criminal Code §364, LAwS OF THE Gambia ch. 37 (rev. ed. 1967); Penal Law, 5737-1977 § 33(b), LAws ST. ISRAEL. (1977); Penal Code $\S 400$, LAws of MaLAwı ch. 7:01 (1968); Criminal Code $\S \S 4,512$, LAws of Nigeria ch. 31 (1973); Criminal Code Act, $1974 \$ \S 4$, 525, Law No. 78 of 1974, Papua New Guinea.

11. See Criminal Attempts Act, 1981, ch. 47, $\S 1$ general note ("Where a person does an act sufficient to constitute an attempt...., there is no rule of common law permitting him to escape conviction for that attempt by evidence that he voluntarily abandoned the attempt ... ."); LAw COMM'N No. 102, ATTEMPT, AND IMPOSSIBILITY IN RELATION TO ATTEMPT, CONSPIRACY AND INCITEMENT If 2.132, at 68 (1980) ("There is no authority to suggest that withdrawal from an attempt ... may at present be raised as a defence."). The abandonment defense is not recognized in England, see G. Williams, Textbook of Criminal LAw 410 (2d ed. 1983), Canada, see E. MEEHAN, supra note 9, at 216, 218-19; D. STUART, CaNAdian CRIMINAL LAw 540-41 (1982), New Zealand, see Regina v. Donnelly, (1970) N.Z.L.R. 980, 990 (N.Z. Ct. App.), or the common law states of Australia, see Regina v. Collingridge, 16 S. Austl. St. R. 117, 131-32 (1976); Rex v. Page, (1933) Vict. L.R. 351, 353-54.

12. Suggestions that abandonment is a defense can be found in Weaver v. State, $116 \mathrm{Ga} .550$, 554, 42 S.E. 745, 747 (1902); People v. Collins, 234 N.Y. 355, 360, 137 N.E. 753, 755 (1922); 
ently and firmly inaintained that "once the eleinents of atteinpt are complete, abandonment of the crimmal purpose is no defense."13

The Proposed Official Draft of the Model Penal Code, however, initiated an era of statutory criminal law reform in this country. Thus, here as elsewhere, the abandonment defense is a legislative product. The pattern was set in the Model Penal Code provision, which declares that, "[w] hen the actor's conduct would otherwise constitute an attempt," it is a "defense that he abandoned his effort to commit the crime or otherwise prevented its commission, under circumstances manifesting a complete and voluntary renunciation of his crininal purpose."14 In the recodifications of criminal law that have since taken place, this provision has been one of the Code's inore successful iunovations: today approximately onehalf of American jurisdictions recognize the abandoninent defense. ${ }^{15}$

Commonwealth v. Tadrick, $1 \mathrm{~Pa}$. Super. 555, 566 (1896), but the courts may be referring to abandonment exclusively during preparation, as iu People v. Lawton, 56 Barb. 126, 133 (N.Y. 1867), and People v. Graham, 176 A.D. 38, 39-40, 162 N.Y.S. 334, 334-35 (1916); see Note, The Proposed Penal Law of New York, 64 Colum. L. REV. 1469, 1521 (1964). Although Wharton advocated a version of the defense, 1 F. WHARTON, CRIMINAL LAW $\S 226$, at 306 (J. Ruppenthal 12th ed. 1932) (1st ed. Philadelphia 1846), his view was adopted only in People v. Von Hecht, 133 Cal. App. 2d 25, 36, 283 P.2d 764, 772 (1955), disapproved in People v. Dillon, 34 Cal. 3d 441, 454 n.2, 668 P.2d 697, 702 n.2, 194 Cal. Rptr. 390, 395 n.2 (1983).

13. People v. Myers, 85 I1l. 2d 281, 290, 426 N.E.2d 535, 539 (1981); accord Lewis v. State, 35 Ala. 380, 389 (1862) ("the attempt was complete; and an after-abandonment by the defendant of his wicked purpose . . . could not purge the crime"); People v. Dillon, 34 Cal. 3d 441, 454, 668 P.2d 697, 702, 194 Cal. Rptr. 390, 395 (1983) ("subsequent events tending to show such an abandonment are irrelevant once the requisite intent and act are proved'(citations omitted)); Wiley v. State, $237 \mathrm{Md}$. $560,564,207$ A.2d 478, 480 (1965) ("[A] voluntary abandonment of an attempt . . . does not expiate the guilt of . . the crime already committed."(citation omitted)); State v. Thomas, 438 S.W.2d 441, 447 (Mo. 1969) ("Once the elements of a criminal attempt are complete, abandonment of the criminal purpose is no defense to a charge of attempt."(citation omitted)); Howard v. Commonwealth, 207 Va. 222, 229, 148 S.E.2d 800, 805 (1966) (" if a man resolves on a criminal enterprise, and proceeeds so far in it that his act amounts to an indictable attempt, it does not cease to be such, though he voluntarily abandons the evil purpose" "(citations omitted)) (quoting Glover v. Commonwealth, 86 Va. 382, 386, 10 S.E. 420, 421 (1889)); State v. Workman, 90 Wash. 2d 443, 450, 584 P.2d 382, 386 (1978) ("Once . . the crime of attempt is accomplished, the crime cannot be abandoned."(citations omitted)).

14. MOdel Penal CODE $\S 5.01(4)$ (Proposed Official Draft 1962). This provision also defines the terms "complete" and "voluntary." For discussion of the Model Penal Code formulation of the defense, see infra Part III, Section $C$.

15. Most of the jurisdictions adopting comprehensive criminal codes in the wake of the Model Penal Code have enacted provisions for the defense. See ALA. CodE $§ 13 A-4-2$ (c) (1982); ALASKA STAT. § 11.31.100(c) (1983); AM. SAMOA CODE ANN. $\$ 46.3403$ (1981); ARIZ. REV. STAT. ANN. $\S 13-1005(A)$ (1978); ARK. STAT. ANN. § 41-704(1) (1977); Colo. REV. STAT. § 18-2-101(3) (1978); ConN. Gen. StAT. ANN. §53a-49(c) (West 1985); Del. CoDE ANN. tit. 11, §541(b) (1979); FLA. STAT. ANN. § 777.04(5)(a) (West 1976); GA. CODE ANN. § 26-1003 (1982); 9 GuAM CODE ANN. § 7.73(a) (1983); HAWAII REV. STAT. § 70S-530(1) (1976); IND. CODE ANN. § 35-413-10 (West 1978); KY. Rev. STAT. ANN. § 506.020(1) (Bobbs-Merrill 1985); ME. REv. STAT. ANN. tit. 17-A, § 154(2)(A) (1983); MINN. STAT. ANN. § 609.17(3) (West 1964); MONT. CodE ANN. § 45-4-103(4) (1985); N.H. Rev. STAT. ANN. § 629:1(III) (1974); N.J. STAT. ANN. § 2C:5-1(d) (West 1982); N.Y. Penal Law \$ 40.10(3) (McKinney 1975); N.D. CENT. Code $\$ 12.1-06-$ 05(3)(a) (1985); Ohio Rev. Code ANN. \$2923.02(D) (Page 1982); Or. Rev. Stat. $\$ 161.430$ 


\section{Abandoned Attempts and the Justification of Attempt Liability}

Recognizing the abandonment defense means defining the dimensions of attempt hability differently in virtue of the post-crime event of abandonment. By applying my general form of argument to this problen of temporal individuation, we can determine whether the law should recognize the defense.

Let us say that there are two kinds of attempt, abandoned and unabandoned, each of which requires justification. The question, then, is whether the prohibition of abandoned attempts is justified. To answer that question, however, we must establish the grounds for prohibiting unabandoned attempts. If the rationale that justifies hability for unabandoned attempts does not similarly justify hability for abandoned attempts, then only the prohibition of unabandoned atteinpts is justified, and the law should recognize the abandonment defense.

II

\section{The Justification of ATtempt Liability}

To establish an adequate justification for criminalizing attempts I will first examine the current major theories of atteinpt liability: the claims that attempt hability is justified because (1) atteinpters are dangerous persons, (2) attempts are dangerous acts, (3) attempts cause social harm, and (4) attempt law authorizes police intervention to prevent the commission of crimes. ${ }^{16}$ By showing the inadequacy of these theories, I

(1985); 18 Pa. Cons. Srat. ANN. §901(c)(1) (Purdon 1983); P.R. LAws ANN. tit. 33, § 3123 (1983); Tex. Penal Code AnN. § 15.04(a) (Vernon 1974); Wyo. Stat. § 6-1-301(b) (1983); Code OF THE FEDERATED StATES OF MicroNeSIA tit. 11, § 201(2) (1982). One state has recognized the defense without legislative action: in Rhode Island, which has no attempt statute, the supreme court adopted the Model Penal Code attempt provision in its entirety. State v. Latraverse, 443 A.2d 890, 893-94, 896 (R.I. 1982).

The statutory provisions for the defense do not apply to crimes other than attempt. See, e.g., Baker v. State, 157 Ga. App. 746, 747, 278 S.E.2d 462, 463 (1981) (arson, assault, robbery); Denman v. State, 432 N.E.2d 426, 433 (Ind. App. 1982) (battery); People v. Vasquez, 85 Misc. 2d 851, 852, 381 N.Y.S.2d 388, 388 (1976) (possession of burglary tools); Commonwealth v. Hubert, $294 \mathrm{~Pa}$. Super. 606, 609, 440 A.2d 630, 632 (1982) (retail theft).

16. This examination of theories of attempt liability is not inclusive. For example, another claim is that attempters should be punished in order to provide an additional deterrent to the commission of substantive crimes. See, e.g., P. Fitzgerald, Criminal Law and Punishment 98 (1962); O. JeNSEN, The NATURE of LeGAl ARGUMENT 160-61 (1957). The usual response is that since attempters intend to succeed, "it is doubtful that the threat of punishment for [attempt] can significantly add to the deterrent efficacy of the sanction-which the actor by hypothesis ignoresthat is threatened for the crime that is his object." MODEL PENAL CODE art. 5 comment at 24 (Tent. Draft No. 10, 1960). H.L.A. Hart labels this response "a fallacy," because there are situations where threatened punishment for attempt may "increase the efficacy of the law's threats." H.L.A. HART, Intention and Punishment, in PUNISHMENT AND ResPonsibility 113, $128-29$ (1968); see Schulhofer, Harm and Punishment: A Critique of Emphasis on the Results of Conduct in the Criminal Law, 122 U. PA. L. REv. 1497, 1538-39 (1974). But these situations are rare (the "perfect crime," for example, where "the chance of discovery is thought to be very slight unless the 
intend to show the need for a better theory. I will then develop my claim that attempt hability should be imposed in order to uphold the substantive rules of criminal law.

\section{A. The Inadequacy of the Major Theories of Attempt Liability}

\section{The Claim that Attempters are Dangerous}

The influential Model Penal Code theory is that "the dangerousness of the actor" 17 justifies the prohibition of attempts. This may be described as the "dangerous-person" rationale of attempt hability.

A dangerous-person rationale can be acceptable, however, only to those prepared to criminalize conduct on the ground that persons who engage in it are dangerous. The Model Penal Code view of attempts is a reflection of the so-called rehabilitative ideal. ${ }^{18}$ Proponents of that "future-oriented predictively based theory of guilt and of punishment"19 may think that personal dangerousness justifies the decision to prohibit attempts equally as much as it justifies sentencing and correctional decisions. $^{20}$ But the rehabilitative ideal has faded in recent years, and they will be obhiged to admit that a dangerous-person rationale "appears strangely out of place in the environment of today's criminal policy."21 It is doubtful that they can explain why personal dangerousness should nevertheless continue to be thought an appropriate basis for criminalizing attempts.

Furthermore, it still must be shown that atteinpters are dangerous persons. The claim is that atteinpters present a "special danger" because they have a disposition to commit crines. ${ }^{22}$ The Model Penal Code cominentary asserts that an attempt "obviously yields an indication that the

plan miscarries," W. LaFave \& A. ScotT, Handbook on Criminal LAW $\$ 59$, at 427 (1972)). Thus, general deterrence of substantive crimes does not adequately justify attempt liability. Nor is it justified by considerations of specific deterrence or of culpability. See infra notes $27 \& 86$.

17. Model Penal Code $\S 5.01$ comment at 26 (Tent. Draft No. 10, 1960).

18. See Weigend, Why Lady Eldon Should Be Acquitted: The Social Harm in Attempting the Impossible, 27 DE PAUl L. Rev. 231, 261 (1978).

19. Enker, Mens Rea and Criminal Attempt, 1977 AM. B. FoUnd. RESEARCH J. 845, 846.

20. See Johnson, The Unnecessary Crime of Conspiracy, 6I CAL1F. L. REV. 1137, 1160 (1973) ("[T]oday we tend to emphasize the restraint or rehabilitation of dangerous individuals. . . . With this change in emphasis have come discretionary and indeterminate sentences, probation and parole systems, rehabilitative prison programs and a wider law of attempts." (footnote omitted)); Wechsler, The Challenge of a Model Penal Code, 65 HARv. L. REv. 1097, 1105 (1952) ("[T] he object is control of harmful conduct in the future. The legislative question therefore is: What past behavior has such rational relationship to the control of future conduct that it ought to be declared a crime?").

21. Weigend, supra note 18 , at 261 . "The rehabilitative ideal, of which the concept of dangerousness is a cornerstone, has recently undergone a rather painful process of demystification. The optimistic view . . . that we are able to diagnose an individual's dangerous propensities and to treat him effectively ... has given way to widespread skepticism." Id. (footnote omitted). See generally F. ALLEN, THE DECLINE of THE ReHABILITATIVE IdEAL. (1981).

22. Model Penal Code art. 5 comment at 25 (Tent. Draft No. 10, 1960). 
actor is disposed towards [criminal] activity, not alone on this occasion but on others." ${ }^{23}$ That assertion, however, is neither obvious nor true. We have no reason to suppose that a single attempt, by itself, indicates that the attempter is disposed to commit crimes. ${ }^{24}$ If instead the claim is that attempts indicate a criminal disposition to the same extent substantive crimes do, ${ }^{25}$ the decisive answer is that the latter indicate no such thing. For, as Professor Gross observes in a related context, "in establishing the basis of criminal hability the law does not concern itself with behavior indicative of a criminal disposition, but only with conduct which it is deeined desirable to prohibit." 26 Of course, any criminal 1might, and some will, commit crimes in the future, and that includes attempters. ${ }^{27}$ But without good reason to behieve tliat all or at least most attempters are disposed to engage in criminal activities, we cannot make the general clann that attempters are dangerous. Consequently, the dangerous-person rationale cannot justify the prohibition of attempts. ${ }^{28}$

23. Id.; see also G. WILLIAMS, supra note $1, \S 203$, at 632 ("The rational course would be to catch intending offenders as soon as possible, and set about curing them of their evil tendencies ...."); Buxton, The Working Paper on Inchoate Offences: (1) Incitement and Attempt, 1973 CRIM. L. REv. 656, 660 ("[P]ersons who threaten to commit acts forbidden by the substantive criminal law . . . are, by reason of their intentions, socially dangerous."); Ullmann, The Reasons for Punishing Attempted Crimes, 51 JuRID. REv. 353, 363 (1939) ("[T]he external criminal act is considered as a mere symptom of the destructive tendencies; the offender appears ... already so dangerous that the law dare not wait for further proofs of his dangerous character ....").

24. One writer finds the statement quoted supra text accompanying note 23 an "astonishing proposition":

This yields the preposterous inference that an unsuccessful effort at one crime proves some special disposition to general crime-doing.... The little gods of evidence who try wisely, if unsuccessfully, to keep evidence of past crimes out of trials for present crimes because of the dubious inferences which might be drawn from past guilt to present guilt, would surely "laugh themselves mortal" at the proposition that a man should be found guilty of a present crime on tlie basis of inferences about future crimes.

Seney, "A Pond as Deep as Hell"-Harm, Danger, and Dangerousness in Our Criminal Law (pt. 2), 18 WAYNE L. REv. 569, 571 (1972).

25. See, eg., R. McConnell, Criminal Responsibility and Social Constraint 71 (1912) ("The would-be criminal who has failed to accomplish his object simply on account of mere chance ... is just as dangerous to society as the criminal who has been more successful."); $c f$. $\mathrm{E}$. FerRi, Criminal Sociology 430-31 (1917) (on social defense theory, the "temibility" or "offensive power" of attempters and succeeders is the same).

26. H. Gross, A THEORY OF Criminal Justice 386 (1979) (discussing theories of punishment); see id. at 35-36; $c f$. Moore, The Semantics of Judging, 54 S. CAL. L. REv. 151, 241 (1981) (arguing that "[o]ne cannot deduce ' $B$ was disposed to do $\mathrm{x}$,' from ' $B$ did $\mathrm{x}$ '").

27. Some writers claim that specific deterrence provides a rationale for attempt liability. See, e.g., G. GoRdon, The Criminal LAW of SCOTLAND 164 (2d ed. 1978); H.L.A. HART, supra note 16, at 128-29. To the extent this claim differs from the dangerous-person rationale, it is a claim (as with substantive crimes) about the justification of pumishment, and tlius it assumes that attempts are properly prohibited.

28. Those who accept a dangerous-person rationale may argue for the abandonment defense on the ground that "renunciation of criminal purpose tends to negative dangerousness." MoDEL Penal Code $\S 5.01$ comment at 71 (Tent. Draft No. 10, 1960); see Royal Comm'N For THE Reform of the Penal Statutes, Report and Preliminary Project for an Italian Penal CODE 214 (E. Betts trans. 1921) ("spontaneous" abandonment "show[s] that the offender is not 


\section{The Claim that Attempts Are Dangerous}

Another theory, proposed by Professor Gross, relies on the dangerousness of the attempter's conduct to justify attempt liability. This theory cannot succeed, however, unless it can be shown that the prohibited conduct is in fact dangerous.

Conduct can be an attempt, Gross claims, only if it poses a threat of harm. ${ }^{29}$ This means, he says, that attempt hability requires sufficiently dangerous conduct. ${ }^{30}$ Whether conduct is sufficiently dangerous, however, is essentially a matter of the likelihood that it will bring about lrarm. ${ }^{31}$ Thus his claim, put in traditional terms, is that conduct, to be an attempt, must be sufficiently proximate to harm. But "liarm," as Gross defines it, necessarily occurs whenever a substantive crime is committed. ${ }^{32}$ This is a misleading stipulative definition, ${ }^{33}$ and it vitiates his theory of attempt hability. For lis claim that conduct must be sufficiently dangerous turns out to be nierely the claim that conduct must be sufficiently proximate to commission of the substantive crime. Gross therefore fails to sliow that the crime of attempt proliibits dangerous conduct. $^{34}$

dangerous, or is so in an insignificant degree"); cf. Bayles, Character, Purpose, and Criminal Responsibility, 1 LAW \& PHIL. 5, 13-14 (1982) (abandonment of atteinpt may rebut inference of undesirable disposition or character trait). The trouble with the argument is that if one believes the claim that attempters have a disposition to commit crimes, one is committed to a strong inference of dangerousness when an attempter crosses the preparation-attempt line. Were that inference strong enough to justify attempt liability, however, it could hardly be outweighed, as a general matter, by "the countervailing inference arising from abandonment." MODEL PENAL CODE $\$ 5.01$ comment at 72 (Tent. Draft No. 10, 1960).

29. H. Gross, supra note 26, at 129 ; see id. at 196 ("An attempt consists of conduct that poses a threat of harm.").

30. Id. at 427.

31. Id. at $79-80,427-28$.

32. "[T] $]$ he term harm ... elnbraces everything that is regarded as an untoward state of affairs by the criminal law in creating liability for the kind of conduet that can, or actually does, bring about such a state of affairs." Id. at 78. Gross's "fuller discussion of harm," id., begins with what seeins to be a new definition: "[H]arm is an untoward occurrence consisting in a violation of some interest of a person." Id. at 115. But any difference between the two definitions, see Levenbook, Review Essay, Crim. JuST. ETHICs, Summer/Fall 1982, at 60, 61-62 (reviewing H. Gross, supra note 26), is unimportant for present purposes. Gross inakes clear that a statement about the harm dealt with by a criminal statute is nothing but "a description of legislative concern." $\mathrm{H}$. Gross, supra note 26 , at 122 .

33. See Levenbook, supra note 32 , at 61 ("It is misleading to speak of harm, or some connection to harm, as a thing that all criminal conduct has in common. This distorts the ordinary ineaning of harm beyond recognition.").

34. On the basis of his account of attempt liability, Gross argues that the abandonment defense should be recognized because "the full course of conduct that includes an effective renunciation is not a criminal act sufficiently dangerous to warrant liability." H. GROss, supra note 26 , at 165 . This argnment, however, incorrectly assesses the dangerousness of a course of conduct. To illustrate degrees of dangerous conduct, Gross uses the example of a would-be assassin lying in wait. Id. at 79, 426, 428-29. If, say, we consider the assassin just before firing-"with his victim fixed in his sights and his finger slowly squeezing the trigger," $i d$. at 428 -we find conduct sufficiently dangerous for 
The failure was inevitable. Although soine attempts are dangerous, many are not. Dangerousness is not a characteristic that attempts share. ${ }^{35}$ Consequently, an adequate justification of attempt liability cannot depend on the dangerousness of the prohibited conduct.

\section{The Claim that Attempts Are Socially Harmful}

Attempts are by definition failures and thus, using ordinary notions of harm, not harmful. ${ }^{36}$ But there is a view that attempts nevertheless do "social" harm. The claim is that attempts are socially harmful, and therefore properly prohibited, because they "provoke public alarm and disturb the public sense of security."37

Let us consider a refined version of this claim, Professor Becker's theory of social volatility. ${ }^{38}$ According to this theory, we will have a satisfactory criterion of criminalization, for both substantive crimes and

attempt liability. If the assassin then decides not to fire and abandons the attempt, we are supposed to consider the entire course of conduct and conclude that it is imsufficiently dangerous for attempt liability. But that conclusion does not follow. Abandonment cannot diminish the dangerousness of the assassin's conduct before abandonment because that conduct has already taken place. Saying that "[d]angerousness of conduct may be diminished," id. at 166, means only that less dangerous conduct may follow more dangerous conduct. Hence, while the assassin's conduct after abandonment was not dangerous at all, an assessment of the conduct as a whole nevertheless finds it as dangerous as its most dangerous part.

35. See Levenbook, Prohibiting Attempts and Preparations, 49 UMKC L. REv. 41, 44-45 (1980); MacKinnon, Making Sense of Attempts, 7 Queen's L.J. 253, 272 (1982). It suffices to mention impossible attempts. See G. Fletcher, Rethinking Criminal LAW § 3.3.3, at 146, $\S 6.2 .2$, at $402-03$ (1978); Weigend, supra note 18, at 258-59.

36. See, eg., J. KLEINIG, PUNISHMENT AND DESERT 132 (1973); Levenbook, supra note 35, at 45 n.17, 52. To claim that attempts are actual harms, J. HALL, GENERAL PRINCIPLES of Criminal Law 217-20, 583-86 (2d ed. 1960), is simply obfuscating. See P. BRETT, AN INQUIRY INTO CRIMINAL GUILT 131 n.8 (1963); O. JENSEN, supra note 16, at 158. If an attempter's conduct causes harm there may be independent liability for that, but then we are not deahing with attempt liability. Cf. Seney, supra note 24, at 593-94 ("A different rationalization for criminalizing attempt focuses ... on the actual harms inflicted by various specific attempts .... However, at this point it seems senseless to continue talking about 'atteinpt.' We would do better to . . . criminaliz[e] those harms directly."(footnotes oinitted)).

37. H. SILVING, Constituent ElEMENTS of CRIME 108 (1967) (citation oinitted); see J. HaLl, supra note 36, at 218 ("Perhaps the common thought underiying these estimates is that in criminal attempts and other relational crimes the harm consists of apprehension and of a dangerous condition in which the probability of still greater harm is substantially increased."); Dressler, New Thoughts About the Concept of Justification in the Criminal Law: A Critique of Fletcher's Thinking and Rethinking, 32 UCLA L. REv. 61, 79 n.116 (1984) ("Frequently the morally based harm is intangible. It may include the injury society suffers when it feels apprehension of possible impending tangible harm, as is the case with the harm expressed by 'atteinpt.' "); Weigend, supra note 18, at 265 ("The relevant harm brought about by the criminal attempt consists in the disruption of the "good order' in the community."). One inay rcasonably doubt that this idea of social harm is even initially plausible. See McGinley, An Inquiry into the Nature of the State and Its Relation to the Criminal Law, 19 OsGoode HaLl L.J. 267, 271 n.18 (1981) ("This idea of community fear is such an odd one and so inconsistent with ordinary perceptions of human nature that one wonders whether it is seriously put forward.").

38. Becker, Criminal Attempt and the Theory of the Law of Crimes, 3 PHIL. \& PuB. AfF. 262 (1974). 
atteinpts, if we interpret "criminal harm as the harm consequent to the social volatility of conduct." 39 Becker's explanation is as follows. People engage in various types of wrongful conduct. But only some types of wrongful conduct sufficiently unsettle others to the point that, as a inatter of self-defense, they will be prepared to depart from socially stable behavior. Such a response to wrongful conduct is "volatile," and if it is community-wide, it is "socially volatile." 40 Hence, the principle for distinguishing criminal from noncriminal wrongs is that only the former give rise to socially volatile responses.

Professor Levenbook has analyzed the main defects in the theory. ${ }^{41}$ Briefly, since almost any type of conduct can provoke a socially volatile response, given a suitable combination of circumstances, the distinguishing primciple is both unhelpful and arbitrary. ${ }^{42}$ Moreover, which types of conduct lead to socially volatile responses may depend "on what already has been labelled as criminal; and if this is so, then the social volatility of an act may be created by prohibiting it." ${ }^{\prime 33}$ It inay work the other way, too. Soine types of conduct may not produce such responses "precisely because they are already controlled (more or less effectively) by the criminal law." 44

Finally, smce noncriminal wrongs inay be civil wrongs, the theory is problematic at a deeper level. For example, Professor Becker says that although promise-breaking can cause social "damage," it should not be a crime because it is "not, at least in our society, typically productive of social volatility." 45 If, however, we hypothesize the absence of other means of legal control, this judgment is questionable. Promise-breaking, were it not subject to civil law, might well be productive of social volatility. If so, then promise-breaking should be criminally prohibited, and that might also be the case with other types of conduct currently treated without controversy as noncriminal wrongs. ${ }^{46}$ On the other hand, if the judgment assumes the existence of civil law remedies, then we have lost the normative primciple for distinguishing between criminal and non-

39. Id. at 275.

40. Id. at 273-74. A socially volatile response, Becker says, has "the potential for destructive disturbance of fundamental social structures." Id. at 273 . This, presumably, makes social volatility "a disvalue in itself, the creation of which . . . is a social harm." Id at 274.

41. See Levenbook, supra note 35, at 53-55; Levenbook, Bibliographical Essay/Criminal Harm, CRIM. JUST. ETHICS, Winter/Spring 1982, at 48, 51-52.

42. See Levenbook, supra note 41, at 51-52 (arguing that "nearly anything" can meet Becker's criterion of criminalization, "given the right mix of mass psychology, mass beliefs (rational or irrational), deinagoguery, and attendant circumstances (like econounic or political probleins and the lack of civil remedies)," and concluding that "Becker's account inakes nearly any act prohibitable").

43. Levenbook, supra note 35 , at 55 (footnote omitted). Similarly, a decision not to prohibit a type of conduct may mean that it will not lead to a socially volatile response. Id.

44. Levenbook, supra note 41 , at 52 .

45. Becker, supra note 38 , at 274.

46. See Levenbook, supra note 41 , at 52 . 
criminal wrongs. In sum, the theory of social volatility does not give us a satisfactory criterion of criminalization and therefore cannot be a satisfactory justification of attempt liability.

\section{The Need to Authorize Police Intervention}

One of the major functions of criminal law served by the prohibition of attempts, according to the Model Penal Code commentary and otlier writers, is to establisl a legal basis for police intervention before substantive crimes are committed. ${ }^{47}$ As a justification of attempt liability, ${ }^{48}$ lowever, this claim is plainly inadequate. It would undoubtedly be foolisli not to authorize the police to intervene im order to prevent tlie commission of crimes. But tliat objective could be fully achieved even "if the only action which could be taken against an attempt were on-tlie-spot prevention of the crime on that particular occasion."49 Hence, to justify attempt liability we cannot rely on the "need for a firm legal basis" for police intervention. ${ }^{50}$ For what is at issue is not police intervention but

47. Model Penal Code art. 5 comment at 24-25 (Tent. Draft No. 10, 1960); see, e.g., W. LAFAve \& A. ScotT, supra note $16, \S 59$, at 426; LAW COMM'N, Working PaPer No. 50, INCHOATE OFFENCES: CONSPIRACY, ATTEMPT AND INCITEMENT \ 73, at 52 (1973); Bubany, The Texas Penal Code of 1974, 28 Sw. L.J. 292, 325 (1974).

48. See C. HowARD, CRIMinal LAw 286 (4th ed. 1982) ("the object of the law of attempt is to justify arrest and prosecution without waiting for [the defendant] to complete the crime"); Enker, Impossibility in Criminal Attempts-Legality and the Legal Process, 53 MINN. L. Rev. 665, 696 (1969) ("this need to stop the defendant before he commits the criminal act ... forces us to fall back upon the crime of attempt"); Note, Effects of the New Illinois Criminal Code on Prosecutions for Inchoate Crimes, 1963 WASH. U.L.Q. 508, 509 ("pumishment . . . is warranted by the necessity of enabling law enforcement officials to intervene").

49. W. LAFAve \& A. ScotT, supra note $16, \S 59$, at 427. Under Terry v. Ohio, 392 U.S. 1 (1968), for example, the police can intervene to prevent commission of a crime whether or not the suspect has committed an attempt or any other crime. Cf. Criminal Attempts Act, 1981, ch. 47, § 1 general note ("But the power of 'authority' physically to prevent crime by 'intervening' at a sufficiently early stage is not in general tied to the commission of an offence of attempt.").

50. Model Penal Code art. 5 comment at 25 (Tent. Draft No. 10, 1960). In part to facilitate earlier police intervention, the Model Penal Code proposes "to extend the criminality of attempts ... by drawing the line between attempt and non-criminal preparation further away from the final act." Id. It may then be said that the abandonment defense is "justified on the ground that the [wider definition of attempt] makes criminal what formerly would have been considered to be mere preparation." California Joint Legislative Comm. For Revision of THE PeNal Code, Penal Code Revision Project $\$ 802$ comment at $116-17$ (Tent. Draft No. 2, 1968); see National Comm'n on Reform of Fed. Criminal Laws, Study Draft of a New Federal Criminal Code $\$ 1001$ comment at 62 (1970); LAW Revision Comm'N, TenNessee Criminal Code and Code of Criminal Procedure § 39-904 comment (Proposed Final Draft 1973). The idea seems to be that without the defense this early liability is "unfair to the defendant who voluntarily abandons." Schulhofer, Attempt, in 1 ENCYCLOPEDIA OF CRIME AND JUSTICE 91, 95 (S. Kadish ed. 1983); see Annual Survey of Rhode Island Law for the 1981-1982 Term, 17 SUFFoLK U.L. REv. 299, 347-48 (1983). But calling the hability "unfair" adds nothing to the statement that a defendant who abandons after crossing the line drawn by the wider definition, but before crossing the line drawn by a narrower definition, should not be liable for attempt. If the additional area of attempt liability is justified, it is no more unfair to hold liable those who abandon early than it is, under a narrower definition, to hold those who abandon later. 
the criminalization of attempts; the need to authorize the former is no reason for the latter. ${ }^{51}$

\section{B. The Rationale that Justifies Attempt Liability: Upholding the Substantive Rules}

We can think of criminal law as a set of rules each of which prohibits or requires the bringing about of a certain state of affairs. ${ }^{52}$ Those rules that one may try (and fail) to violate I will call "substantive rules." Assuming that substantive rules are in effect, it is possible to provide for attempt hability by adding a nonsubstantive rule-an attempt rule - that prohibits trying to violate any of the substantive rules. ${ }^{53}$ Should the law add an attempt rule prohibiting unabandoned attempts?

Suppose I address the lawnakers as follows:

I agree that there are good reasons for prohibiting murder, rape, and robbery, and even such activities as evading customs duties and receiving stolen property. I have no quarrel with the substantive rules, and I can understand why I should not break them. But merely trying to break them is altogether different. Why should I be prohibited from merely trying to murder or rob or receive stolen property?

This statement has a peculiar ring to it. I cannot consistently accept the substantive rules and, at the same time, try to break them. The lawmakers might therefore be teinpted to reply that since $I$ agree that

51. Cf. Criminal Attempts Act, 1981, ch. $47, \S 1$ general note ("[T] he doing of an [attempt] act ... provides appropriate grounds for ... conviction ...; and it will in some, but maybe relatively rare, cases provide also the earliest occasion for lawful physical intervention."); Temkin \& Zellick, Attempts in English Criminal Law, 1 DaLHousIE L.J. 581, 590 (1974) ("[I]t is idle to seek to formulate a [definition of attempt] until we have determined what stage in any sequence of actions leading towards the commission of a crime ought to justify both police intervention and criminal conviction; and that is as much a moral as a legal enquiry." (emphasis added)); Weigend, supra note 18 , at $263 \mathrm{n} .171$ ("While [crine prevention] is a commendable purpose, the preventive interests of the police furnish no grounds for the subsequent punishment of the would-be offender.").

Of course, it does not follow, from the ability of the police to prevent commission of a crime on a particular occasion, that an attempter should not be subjected to "stronger preventive measures," such as prosecution and conviction. W. LAFAVE \& A. ScoTT, supra note 16, \&59, at 427. But then the justification of attempt liability would not be the need to authorize police intervention, but rather the dangerous-person rationale. See supra text accompanying notes 17-28.

52. Cf. H.L.A. HART, THE CONCEPT OF LAW 27, 78-79 (1961) (rules of criminal law impose duties to do or avoid certain actions); Glassman, Why Don't We Teach Criminal Law?, 15 J. LEGAL EDUc. 37, 42 (1962) (criminal law can be described as a set of rules of conduct).

53. Unless we are talking about trying, we are not talking about attempting. See P. BRETT, supra note 36, at 133 ("It has always been accepted that there cannot be an attempt unless the defendant was trying to commit a crime. 'To attempt' is, indeed, synonymous with 'to try.' "); $H$. Packer, The Limits of the Criminal Sanction 100 (1968) ("The gist of attempt is that the actor has tried to do something but has not succeeded."); G. WiLliams, supra note 11, at 405 n.3 (viewing crime of attempt as "a general edict that no one must even try to commit a crime"); Hughes, One Further Footnote on Attempting the Impossible, 42 N.Y.U. L. REV. 1005, 1026 (1967) ("[A]n attempt must be understood as including a reference to trying to achieve the actus reus of the complete crime ...."). 
there are good reasons for the substantive rules, I should also agree, without more, that there is good reason for the attempt rule. But we should be able to say more in favor of attempt liability than that we include both the doing and the trying whenever we establish a standard of conduct by enacting a substantive rule. ${ }^{54}$

Consider what the attempt rule prohibits. Trying is goal-seeking activity; when you try to do something, you necessarily act in pursuit of a certain goal or objective. ${ }^{55}$ If substantive rule $S$ prohibits bringing about state of affairs $A$, and you try to bring about $A$, then your goal is a violation of $S$. You are trying to do what $S$ prohibits you from doing. Hence, when you try to break a substantive rule, your conduct challenges the normative authority of that rule. ${ }^{56}$ Thus, prohibiting unabandoned attempts maintains the authoritative force of the substantive rules agamst conduct that challenges them.

We can also look at the attempt rule from a shightly different angle. Suppose the law gave you a choice between complying with the substantive rules or violating them and risking the consequences. ${ }^{57}$ The attempt rule would then be paradoxical, for trying to bring about $A$ would be part of the process of exercising the choice given you to violate $S$. But in fact the law does not give you that choice. The substantive rules are categorical directions for conduct. If you try to break a substantive rule, agents of the law will ordinarily seek to prevent your success. Prevention often includes forms of restraint that make success physically impossible-an especially graphic method of showing that the law gives no such choice. ${ }^{58}$

54. One who thinks we need say no more necessarily loolds that attempt liability requires no independent justification. See infra note 60.

55. "[T]rying is not sometling the agent does witlin limself. It is a characterisation of his doings, or lack of them, in relation to their assumed goals." Heath, Trying and Attempting, 45 Proc. ARISTOTELIAN Soc'y SUPP. Vol. 193, 196 (1971). Conduct, in other words, cannot be characterized as trying in the absence of a goal. See id. at 196-203; see also F. OPPENHEIM, DIMENSIONS OF FREEDOM 33 (1961) ("To attempt to do sometling is to do sometling which one believes, rightly or wrongly, to be conducive to one's goal. That $\mathrm{X}$ attempts $\mathrm{x}$ implies that $\mathrm{X}$ lad alrcady chosen $x$ as a goal and performed part of the course of action lie expects to lead to it, but not the wliole of it."(footnote omitted)).

56. Cf. McGinley, supra note 37, at 283 ("Attempt is ... a pure exercise in disobedience.").

57. In a discussion of excuses, H.L.A. Hart once suggested a "mercantile analogy," by which criminal law is viewed as "a choosing system in which individuals can find out, in general terms at least, the costs they liave to pay if they act in certain ways." Hart, Legal Responsibility and Excuses, in Determinism AND FREEdoM IN THE AGE OF MODERN SCIENCE 81, 96 (S. Hook ed. 1958). For an economist's negative response to this analogy, see Lerner, Punishment as Justice and as Price; On Randomness, iu Determinism AND Freedom in tHe AGE OF MODERN SCIENCE 180, 181-82 (S. Hook ed. 1958).

58. "The state clearly does not give a cloice whether to commit a crine, althougl such a choice must necessarily exist for an act of disobedience to occur. . . Crimes must be performed surreptitiously not simply because they will be punisled but also because they will be prevented if anticipated." McGinley, supra note 37, at 283. 
But providing for attempt hability is a complementary method, ${ }^{59}$ which may be equally cogent. Were there no attempt rule, the law would to that extent suggest that compliance with the substantive rules is a matter of choice. Thus, prohibiting unabandoned attempts maintains the standing of the substantive rules as requireinents that must be observed.

The significance of the substantive rules is what counts. They estabhish basic standards of conduct, standards we beheve it inportant to uphold. It is therefore important to uphold the substantive rules themselves. The attempt rule demonstrates that the substantive rules inust be taken seriously. ${ }^{60}$ It also demonstrates that we take thein seriously. In summary, then, we prohibit unabandoned attempts in order to uphold the substantive rules.

The question is whether we now have good reason for imposing attempt hability. It should not be objected that we have no reason at all. That would be either to suppose that prohibiting unabandoned atteinpts does not uphold the substantive rules, which is incorrect; or else to suppose that we do not or should not care about upholding the substantive rules, to which the answer is that we both do and should, for otherwise we would not have enacted them. But it imight be argued that although we have some reason, we do not have adequate reason for prohibiting unabandoned atteinpts. Granted that we thereby uphold the substantive rules, we already uphold thein by enforcing thein; it is not necessary to provide for attempt liability as well. What follows froin the absence of such necessity, however, is only that we do not have conclusive reason for prohibiting unabandoned atteinpts. We may nevertheless have good reason, and that is the criterion of adequacy.

I beheve that what has been said above quahifies as good reason. Attempt hability sufficiently serves the purpose of upholding the substantive rules, and upholding thein is sufficiently important, to warrant the judgment that there is good reason for imposing it. We would not be according the substantive rules the significance they should have if we did not prohibit the conduct of those who try to violate thein. There are better reasons for prohibiting conduct-that it harms people, for onebut we have good enough reason for prohibiting unabandoned attenpts.

This is not to deny that there may be reasons to the contrary. We might be concerned, for exainple, that the difficulty of obtaining evidence

59. See id. ("[One] indicator of the absence of a given choice is the fact that the state will punish those who even attempt to perpetrate the more serious offences.").

60. It may be, of course, that a "way[] of ensuring that they are taken seriously is to punish not only those who break then, but those who try to break them." MacKinnon, supra note 35, at 260. But referring to the punishnent of attenupters can be misleading in this context. For unless one holds that the prohibition of unabandoned attenupts requires no independent justifieation, one cannot justify the punishment of attempters without first justifying that prohibition. (Just as, for example, one cannot justify the punishment of nurderers without first justifying the prohibition of murder.) 
will stimulate objectionable investigative practices or that the imprecise formulation of the attempt rule will lead to haphazard or discriminatory apphication. As in any criminalization decision, we have to determine that the reasons for prohibition outweigh the reasons against in order to conclude that, all things considered, the law should adopt an attempt rule. ${ }^{61} \mathrm{My}$ claim, then, is to have established the prima facie justification of attempt liability.

\section{III}

\section{The Case for the Abandonment Defense}

Having estabhshed the rationale that justifies attempt liability, the next step is to determine whetler that rationale similarly justifies hability for abandoned atteinpts. I conclude that it does not. Hence, subject to possible objections, which I discuss below, ${ }^{62}$ the law should recognize tlie abandonment defense.

\section{A. The Argument for the Defense}

Assume that an atteinpt rule prohibiting unabandoned attempts is in effect. It is now possible to provide for "abandoned-attempt liability" by adding an "abandoned-attempt rule" prohibiting conduct that would have violated the attempt rule liad there been no abandonment. To decide whether to add this abandoned-attempt rule is to decide whether to recognize the abandonment defense.

It is important to understand the difference between abandoned and unabandoned attempts. One violates the attempt rule when one tries to violate a substantive rule. One violates the abandoned-attempt rule when one's conduct would have violated the attempt rule liad one not abandoned. It miglit therefore seem that, in violating the abandoned-attempt rule, one tries to violate a substantive rule and then abandons. That, however, is not so.

One can try to achieve a goal without taking all the steps necessary for achieving it. One inay take half the steps, whicl may then count as

61. The strength of countervailing reasons may vary with different substantive rules and different circumstances. It may even be appropriate not to enact a general attempt statute, but rather to treat the question separately for each substantive crime. One jurisdiction has recently adopted this approach. See Dunahoo, The New Iowa Criminal Code, 29 Drake L. REv. 237, 32528 (1979-80); cf. Arnold, Criminal Attempts-The Rise and Fall of an Abstraction, 40 YALE L.J. 53 (1930) (advocating this approach for courts). Federal law has never contained a general attempt statute, and there is resistance to enacting one. See House COMM. ON THE JUDICIARY, CRIMINAL Code Revision ACT OF 1980, H.R. ReP. No. 1396, 96th Cong., 2d Sess. 83-84 (1980) (noting that general attempt statute would expand federal jurisdiction, thus altering federal-state balance); Quigley, The Federal Criminal Code Revision Plan: An Epitaph for the Well-Buried Dead, 47 GEo. WASH. L. REv. 459, 466-67 (1979) (arguing that general attempt statute would be subject to prosecutorial abuse).

62. Infra Part III, Section $D$. 
trying to achieve the goal. But taking half the steps cannot count as trying if one then changes one's mind and abandons one's effort:

Suppose I have decided to try to get to B from A via an inevitably long and complicated route, but half-way through my journey I learn of a mishap to one of my children at home and decide to break off my engagement and turn straight back home. I was, for a certain period of time, in process of trying to get to $\mathrm{B}$, but it would hardly follow, nor be true, that I tried to get to $\mathrm{B} .{ }^{63}$

One may, of course, be very close to one's goal before one abandons. Suppose we agree to meet for dinner. I drive downtown, park my car, and walk several blocks to the restaurant. If, as I am about to open the door, I change my mind and go to a movie down the street, I cannot later tell you truthfully that I tried to meet you for dinner. By contrast, if the police arrest me on an old warrant and drag me off to jail, then I did try to meet you for dinner. ${ }^{64}$ Or suppose you hire me to kill your enemy $V$. Owing to the difficulties imvolved ( $V$ lives in a fortress, has bodyguards, etc.), you agree to pay me in full even if I try but fail. I surmount all the difficulties but, as I am on the verge of shooting $V$, I decide that I do not want to be a killer, change my mind about killing $V$, holster my gun, and leave. If I thereafter claim my fee, pointing out that I did every bit as much work as if $V$ 's bodyguards had, at the last second, prevented me from shooting $V$, you will correctly inform ine that, hypotheticals notwithstanding, I did not try to kill $V .65$

The very same actions may thus count as trying to do something in one case but not in another. This is so because trying is a characteriza-

63. Jones, Trying, 92 MiND 368, 374 (1983); see Broadie, Trying and Doing, 66 Proc. ARISTOTELIAN SOC'Y 27, 28 (1965-66) ("But it does not necessarily follow that because someone has failed to do $X$, he could only have been trying to. He may have, when he found himself failing; but he may also have given up.").

64. "In the primary sense of 'try' the agent engages to do what it would not be unreasonable of him to regard himself as not sure to succeed in doing ...." Broadie, supra note 63, at 28. It is thus "required that there should be an appropriate element of epistemological uncertainty in the situation," Jones, supra note 63 , at 371 , and if I had no reason to expect that I would be arrested on my way to meet you, it may seem that this requirement is not met. But in fact it is: "The agent may be proceeding soberly and without effort to his goal; yet a sudden extraneous occurrence may defeat him, and the mere fact of this is enough to turn his ease into one of trying, which it was not before." Heath, supra note 55, at 196; see I. THALBERG, Some Puzzles About Effort, in EnIGMAS of AgENCY 87, 91-92 (1972) ("The epistemic criterion is asymmetrical with regard to tenses of the verb 'try' .... [T]alk of past attempts does not presume that there was any doubt that the agent could carry out his intention.").

65. Although we are concerned here with the crime of attempt, it is useful to consider situations where trying to do something precludes liability. For example, a corporate crime of "reactive noncompliance" might be defined as "a failure to comply with a legally imposed reactive duty, subject to an affirmative defense that the corporation exercised due diligence in attempting to comply." Fisse, Reconstructing Corporate Criminal Law: Deterrence, Retribution, Fault, and Sanctions, 56 S. CAL. L. REv. 1141, 1202 (1982). If a corporation took steps to comply with its statutory duty, but abandoned the effort before completing the necessary corrective measures, then it did not try to comply and should not be entitled to a defense of attempted compliance. 
tion of conduct in relation to a goal, and it requires that, insofar as I can, I continue acting towards iny goal. I need not be forcibly restrained froin proceeding further, for I inay have chosen ineffective ineans, I inay lack the ability to pull it off, or I may just be sloppy. ${ }^{66}$ Yet I have tried nevertheless. And it is true that "[i]n describing soineone as trying to do something, we are not limited to effort which represents great commitinent or which is likely to be successful." ${ }^{\prime 67}$ But we are limited to the conduct of those who, to the extent they can, continue in their efforts to achieve their goals. ${ }^{68}$ If $I$ change iny mind and abandon iny effort, I do not meet that requirement. Accordingly, when my conduct is appraised in relation to my goal, it cannot be characterized as trying. To describe my conduct I may say, "I was, for a certain period of time, in the process of trying to achieve the goal," "I took a number of steps towards the goal," and so forth. But I will have to add that I then changed my inind and abandoned, thereby confessing that I did not try to achieve my goal.

Let us return to the rules. Assuine that a substantive rule prohibits bringing about state of affairs $A$. Also assume that your goal is to bring about $A$, that to bring about $A$ you decide to do acts $B$ and $C$, and that doing $B$ inay count as trying to bring about $A$. Now if you do $B$ but are arrested before you can do $C$, then you have violated the attempt rule because you tried to bring about $A$. On the other hand, if you do $B$ but change your inind and abandon your effort to bring about $A$, and so do not do $C$, then you did not try to bring about $A$. You have not violated the atteinpt rule. You have, however, violated the abandoned-atteinpt rule; your conduct would have counted as trying to bring about $A$ had you not abandoned.

The question, then, is whether the rationale that justifies attempt liability justifies abandoned-atteinpt hability as well. Unabandoned attempts are prohibited im order to uphold the substantive rules. But we cannot make this claim about abandoned attempts.

We do not uphold the substantive rules by prohibiting the conduct of those who, having abandoned their efforts, did not try to break the rules. First of all, the prohibited conduct in no way challenges the norinative authority of those rules, which means that the abandoned-atteinpt rule is incapable of maintaining that authority. In addition, since the

66. See H.L.A. HART, The House of Lords on Attempting the Impossible, in EsSAYS IN JURISPRUDENCE AND PHILosophy 367, 372 (1983) ("[T] There are many kinds of attempt . . . which fail not because of any interruption, but are doomed to failure from the start because the means chosen for the commission of the intended crime is misdirected or insufficient.").

67. MacKinnon, supra note 35 , at 260.

68. See Jones, supra note 63 , at 374 :

What seems to be required is that I continue with the process to the best of my ability ... (with room for variation between cases where I do all I can-try very hard, and cases where I do not do everything I can-I try, but not as hard as I could). 
prohibited conduct is not the exercise of a choice to break the substantive rules, providing for abandoned-attempt hability cannot show that the law gives no such choice. Hence, the abandoned-attempt rule cannot maintam the status of the substantive rules as mandatory directions for conduct. Furthermore, since violators have not tried to break substantive rules, the prohibited conduct does not reflect failure to take the rules seriously. In short, we do not uphold the rules by prohibiting conduct not aimed at violatimg them. The considerations justifying attempt liability give us no reason for prohibiting abandoned attempts.

\section{B. Three Unsatisfactory Arguments for the Defense}

It would not be inconsistent with iny argument to claim that there are reasons for recognizing the abandonment defense that are independent of any particular theory of attempt hability. I will exaimine and reject three such arguments: (1) the availability of the defense encourages atteinpters to abandon; (2) abandonment negates the intent required for attempt; and (3) attempters who abandon lack the necessary culpability. ${ }^{69}$ The defense follows from the justification of attempt liability or not at all.

69. The "probable desistance" test of the sufficiency of conduct for attempt is often assumed to imply that abandonment is a defense. See, e.g., C. HowARD, supra note 48, at 295; Hoyles, The Essentials of Crime, 46 CAN. L.J. 393, 410 (1910). But see Berry v. State, 90 Wis. 2d 316, 327, 280 N.W.2d 204, 209 (1979) (abandonment no defense under Wis. STAT. ANN. § 939.32(2) (West 1982), which provides for probable desistance test), cert denied, 444 U.S. 1020 (1980). As conventionally formulated, the test requires conduct that "im the ordinary course of events would result in the commission of the target crime except for the intervention of some extraneous factor." W. LAFAvE \& A. ScoTT, supra note $16, \S 59$, at $434-35$ (footnote omitted). Hence, when the defendant abandons, one might suppose that since it can hardly be true that the defendant would have completed the crime but for "some extraneous factor," the defendant's conduct cannot be sufficient for attempt. But this is a misunderstanding of the nature of the probable desistance test.

Conduct is sufficient under this test once it reaches a point where it is reasonable to judge that the defendant, uuless stopped, will continue and do the last act. This judgment is a counterfactual prediction rather than a prediction of what will actually happen. Thus, as applied to a defendant arrested at some point before doing the last act, the test requires a prediction that the defendant, having reached that point, would have continued and (if not stopped) done the last act or, equivalently, would not have abandoned before doing the last act. That prediction can be counterfactually correct (reasonable) or incorrect (unreasonable), and if we believe it to be the former, then we find the defendant's conduct sufficient for atteinpt. It follows that there is no contradiction in finding conduct sufficient when the defendant abandons. Although abandonment may seem to refute the prediction, the appearance is deceptive. A counterfactual prediction can be evaluated as correct or incorrect only in relation to the time-bound evidence on which it is grounded. To be sure, the defendant's abandonment might east doubt on the correctness of the prediction made in the defendant's case. Indeed, repeated abandonments in similar cases would eventually lead us to evaluate the prediction as incorrect even when defendants do not abandon. But in any one case there is nothing formally inconsistent in ignoring the defendant's abandoninent and adhering to what we believe to be a correct counterfactual prediction. 


\section{The Argument that the Defense Will Encourage Abandonment}

Attempters are often in situations where, unless they abandon their efforts, they are likely to succeed. So, it is argued, the defense should be recognized in order to encourage abandonment, "thereby diminishing the risk that the substantive crime will be committed."70

Proponents of this argument often assume that without the defense abandonment will have "no legal effect."71 But in inost jurisdictions the penalties for attempts are less than the penalties for the respective substantive crimes. ${ }^{72}$ In inost jurisdictions, then, the argument requires the existence of attempters who, despite the greater penalty for the crime attempted, will not abandon unless abandonment is also a defense to atteinpt. ${ }^{73}$ On the assumption that the penalty structure already encourages abandonment, the existence of such atteinpters is doubtful. ${ }^{74}$

But the crux of the matter is whether the defense will encourage abandonment in any event. The claim presupposes that some attempters will be aware of the defense. Assuming this awareness, the question is

70. Model Penal Code $\S 5.01$ comment at 72 (Tent. Draft No. 10, 1960). For a sample of the many writers who use this argument, see G. GoRDON, supra note 27, at 182; E. MEEHAN, supra note 9, at 223-24; Noone, Preliminary Crimes: The Reform of Attempt and Conspiracy in Papua New Guinea, 2 Melanesian L.J. 66, 87 (1974); Ryu, Contemporary Problems of Criminal Attempts, 32 N.Y.U. L. REv. 1170, 1199 (1957); Note, Reforming the Law of Inchoate Crimes, 59 VA. L. REv. 1235, 1247 (1973); Note, Attempt, Solicitation, and Conspiracy Under the Proposed California Criminal Code, 19 UCLA L. REv. 603, 613 n.61 (1972).

71. Schwenk, Criminal Codification and General Principles of Criminal Law in Argentina, Mexico, Chile, and the United States: A Comparative Study, 4 LA. L. REv. 351, 367 (1942).

72. See Robinson \& Grall, Element Analysis in Defining Criminal Liability: The Model Penal Code and Beyond, 35 STAN. L. REv. 681, 736 \& n.248 (1983). The encouragement argument has long been relied on to support reduced penalties for attempts. See S. AMOS, THE SCIENCE OF LAW 254 (7th ed. 1889); C. BECCARIA, ON CRIMES AND PUNISHMENTS 40 (H. Paolucci trans. 1963) (1st ed. Tuscany 1764); J. Bentham, Principles of Penal Law, in 1 The Works OF Jeremy Bentham 365, 561 (J. Bowring ed. 1843).

73. Compare Skilton, supra note 1 , at 310 n.4 (arguing that defense is unnecessary because "avoidance of these greater penalties is sufficient incentive to abandon") with Hall, Criminal Attempt-A Study of Foundations of Criminal Liability, 49 YALE L.J. 789, 830 n.162 (1940) ("[I]n addition to the sanction of the cousummated crime, [the law] holds up the prospect of complete freedom from liability as an additional incentive to desist.").

74. Another objection is that encouragement can be at most the basis for a mitigation defense, as there is even less reason to suppose that there are attempters who will not abandon if there is a mitigation defense, but will abandon if there is a complete defense. But see MODEL PENAL CODE $\S 5.01$ comment at 73 (Tent. Draft No. 10, 1960) (" $[R]$ eductions in sanction would have to be very great in order to have a substantial impact on those already engrossed in a criminal attempt; indeed it is unlikely that anything short of complete immunity would suffice."). For reliancc on encouragement to support a mitigation defense, see G. WILliAMS, supra note $1, \S 199$, at 621 ; Michael \& Wechsler, A Rationale of the Law of Homicide (pt. 2), 37 CoLUM. L. REV. 1261, 1295 n.81 (1937). Statutory mitigation provisions for abandoned attempts have been supported on this ground. See Parliament of the Commonwealth of Austl., Parliamentary Paper No. 44, Draft CRIMINal Code For THE AustraliaN Territories $\$ 54$ comment at 21 (1969); Wisconsin Legislative CounCIL, 1950 RePort ON THE CRIMINAL CODE $\$ 339.20$ comment at 28 (1951). 
whether any of these attempters will abandon because of the defense. The possibility of avoiding attempt hability is not by itself a motive for abandoning an attempt. So the claim must be that there are attempters who, though they have a motive to abandon, would nevertheless decide not to abandon, except that they know abandonment is a defense. Although this might happen, we have no good reason to believe it would be anything other than very unusual. We may hope that some attempters will abandon their attempts because of the defense, but the claim that they actually will is an article of faith.

Even if recognition of the defense will encourage abandonment, a diminished risk of substantive crimes will not necessarily follow. For if knowledge of the defense will also encourage people to make attempts they would not otherwise make, ${ }^{75}$ and if not all such attempts will be abandoned, then the number of these encouraged attempters might equal or exceed the number of attempters who abandon because of the defense. We thus have no grounds for claiming that the defense will prevent more substantive crimes by encouraging abandonment than it will produce by encouraging attempts.

\section{The Argument that Abandonment Negates the Requisite Intent}

Another argument for the defense, offered by Professor Fletcher, rehies on the intent required for attempt. Fletcher clamis that this requirement excludes abandonment cases because abandonment "reveals that the actor's criminal will was imsufficiently resolute to carry through."76 The argument, he says, is not that "abandonment raises doubts about the actor's intention up to that time. The principle . . . is that the intent required for an attempt is not merely a firm resolve up to the time the attempt is complete as a pumishable act. The intent required is one to carry through." $" 77$

We can expose the miplausibility of this argument by considering a crime like burglary - breaking and enterimg with intent to commit a felony-which requires what Fletcher calls an "unexecuted intent added to a consuminated act."78 Imagine a would-be rapist, $X$, who breaks and enters with intent to commit rape. $X$ 's breaking and entering, we may assuine, is conduct sufficient for attempt liability as well. If $X$, after

75. See, eg., De Cicco, Proposed New Jersey Penal Code, 1 CRIM. JusT. Q. 164, 170-71 (1973). It has been replied that this "presumes that the actor plans to withdraw all along and thus never commits himself to consummating the substantive crime." Note, Criminal Attempt, Conspiracy, and Solicitation Under the Criminal Code Reform Bill of 1978, 47 GEO. WASH. L. REv. 550, 571 n.206 (1979). These encouraged attempters, however, need not plan to abandon, and once they begin some of them may finish.

76. G. FLETCHER, supra note 35, § 3.3.8, at 194.

77. Id. at $187-88$ (footnote omitted).

78. Id. $\S 6.5 .6$, at 454 . 
entry, changes his mind and abandons his effort, he will still be liable for burglary because he broke and entered with intent to commit rape. $X$ 's abandonment does not show that he lacked the requisite intent. But, on Fletcher's argument, he will not be hable for attempted rape because he did not have the intent to commit rape. $X$ 's abandonment shows that he lacked the requisite intent. If, then, we accept this view of "the peculiar quality of the intent required for an attempt,"79 we are forced simultaneously to hold both that $X$ 's abandonment does, and that it does not, negate his intent to commit rape. ${ }^{80}$

There is nothing inysterious about the relationship between abandonment and the intent requirement for attempt. An attempter must intend to engage in conduct or cause a result that constitutes the substantive crime attempted. ${ }^{81}$ When you have this intent and act in furtherance of it, you can be described as having a further imtention in acting or an "intention with which" you do what you do. ${ }^{82}$ It is therefore incorrect to say that the attempter who abandons necessarily lacks the requisite intent. Assume, for example, that you forn the intention to bring about prohibited state of affairs $A$, which requires you to do a set of acts $B$ and a final act $C$. Assnme that you do $B$, which is conduct sufficient for attempt hability, and that thereafter you do $C$ but fail, for some reason, to bring about $A$. In that case, by hypothesis, attempt hability attached when you did $B$. But suppose instead that, after doing $B$ and before doing $C$, you change your mind and give up your intention. In this case too (absent provision for the abandonment defense) you are hable for atteinpt: you perforned sufficient acts with the intention of bringing about $A$. Your change of mind confirms rather than refutes the existence

79. Id. $\$ 3.3 .8$, at 187. Fletcher's claim that this intent requirement is "implicit in the concept of attempting," id. at 189 , appears to be purely ad hoc.

80. The implausibility of Fletcher's argument for the abandonment defense may also be illustrated with larceny, which he refers to as a "completed" crime for which, unlike attempt, abandonment is irrelevant. Id. at 186. Larceny requires " an intent permanently to deprive the owner of his property." "Id. $\S 6.5 .2$, at 443 . Now suppose we define an aggravated form of larceny as "permanently depriving the owner of his property." It will then be attempted aggravated larceny" to take property with intent to deprive the owner of it permanently. On Fletcher's view of the intent required for attempt, the attempter's abaudonment will negate the requisite intent. Yet attempted aggravated larceny is identical to ordinary larceny.

81. In attempt statutes, this intent requirement is often specified as acting "with intent to commit a crime." See, e.g., ALASKa STAT. \$ 11.31.100(a) (1983); MINN. STAT. ANN. § 609.17(1) (West 1964); N.Y. PENAL LAW $\S 110.00$ (McKinney 1975). For sophisticated discussions of intent and attempt, see J. MEILAND, The NATURE OF INTENTION 66-73 (1970); Chisholm, The Structure of Intention, 67 J. PHIL. 633, $641-43$ (1970); Pitcher, "In Intending" and Side Effects, 67 J. PHIL. 659 (1970).

82. G. ANSCOMBE, INTENTION 30-31, 34-35 (2d ed. 1963); see H.L.A. HART, supra note 16, at 117-18, 125-26; J. MEILAND, supra note 81, at 8-9; Gustafson, Passivity and Activity in Intentional Actions, 90 MIND 41, 55 (1981); Levenbook, supra note 35, at 51. Another way to put it is to say that the prohibited state of affairs is the reason for your action. See Moore, Responsibility and the Unconscious, 53 S. CAL. L. REV. 1563, 1614 (1980). 
of the requisite intent. ${ }^{83}$

\section{The Argument that Attempters Who Abandon Are Not Culpable}

Considerations of culpability have been rehed on to support the defense. ${ }^{84}$ Thus Professor Kelman mentions the argument that "abandonment makes us reassess our vision of the defendant's blameworthiness." ${ }^{85}$ It is unclear, however, what it means to say that we reassess the defendant's blameworthiness. Since attempters are culpable for their attempts, ${ }^{86}$ the point might be that the defendant's abandonment is "a praiseworthy act that erases the defendant's original blameworthiness."87 But if this is what it means to reassess blameworthiness, the argument cannot succeed, because nothing that happens afterwards can retroactively affect the defendant's culpability for prior conduct.

Perhaps the argument means that we are to reassess the defendant's blameworthiness as a person. ${ }^{88}$ Consider $X$ and $Y$, planming to murder

83. See J. MEILAND, supra note 81, at 11 (necessary condition of purposive intention to bring about state of affairs is that one can change one's mind about bringing about that state of affairs); $i d$. at 114 ("the agent's changing his mind about doing $X$ is a way of his ceasing to intend to do X").

84. A related claim is that the defense should be viewed as a "reward." See G. Fletcher, supra note 35, § 3.3.8, at 187 n.142; J. SAMAHA, CRIMINAL LAW 423 (1983); 1 Revised PENAL CODE art. 6 comment at 96 (L. Reyes 9th ed. 1971) (Phil.). But we have to distinguish between rewarding attempters who abandon and rewarding attempters $t o$ abandon. The latter merely repeats the encouragenent argument. See supra text accompanying notes 70-75. The former needs a reason. It might be said that attempters "deserve" a reward for abandoning, but, apart from the question why the reward should take the form of a defense, see Skilton, supra note 1, at $310 \mathrm{n} .4$ (defendant's nonliability for crime attenpted "is sufficient reward for his repentance"), this claim is too uninformative to be persuasive.

85. Kelman, Interpretive Construction in the Substantive Criminal Law, 33 STAN. L. REv. 591, 612 (1981).

86. To say that attempters are culpable for their attempts is not to say that culpability is a justification of attempt liability. Although it may be that "exculpation [of attempters who fail "due to a fortuity"] would involve inequality of treatneent that would shock the common sense of justice," MODEL PENAL CODE art. 5 comment at 25 (Tent. Draft No. 10, 1960), that can be so only on the assumption that attempts are properly prohibited. It is a separate question whether attenpters and succeeders are equally culpable and thus should receive equal penalties. For diverse views in that perennial debate, see D. Richards, The MORAL CRITICISM OF LAW 202 (1977); Brady, Punishing Attempts, 63 MoNisT 246, 255-56 (1980); Dworkin \& Blunenfeld, Punishment for Intentions, 75 Mind 396 (1960); Marlin, Attempts and the Criminal Law: Three Problems, 8 OTTowa L. Rev. 518, 535 (1976); Moore, supra note 82, at 1613 \& n.151; cf. PLATo, LAWs 876e-877b, translated in THE LAWS OF PLATo 272-73 (T. Pangle trans. 1980) (no death penalty for atteinpted inurder, "out of reverence for [the attempter's] not entirely bad luck" and "to show gratitude to [the] demon" who prevented the victim's death).

87. P. Low, J. JefrRies \& R. Bonnie, Criminal LaW: Cases and Materials 351 (1982); see Wasik, Abandoning Criminal Intent, 1980 CRIM. L. REv. 785, 787-88 (noting claim that abandonnent "is a 'good act' which somehow compensates for . . . the initial criminal act").

88. This possibility is implicit in Kelman's response to the argument: "Of course, if we admitted evidence of post-crininal conduct (whether remorse, restitution, condonation, or reform) into every trial, we would frequently change our views of the defendant's blameworthiness." Kelman, supra note 85, at 612 . The defendant's remorse, restitution, or reform will not, however, "change our views of the defendant's blameworthiness" for prior conduct. But we inight changc our 
their respective spouses by putting poison in the inorning coffee. $X$ pours his wife a cup of poisoned coffee; she takes a sip, but immediately spits it out and throws the coffee away. $Y$ likewise pours her husband a cup of poisoned coffee; he is about to take a sip, but before he does $Y$ changes her mind, snatches the cup out of his hand, and throws the coffee away. On these facts, we would probably judge $Y$ to be a less blameworthy person than $X$. We might explain this judgment by saying that $X$, by -doing what he did, has becoine a worse person than $Y$ has become by doing what she did. ${ }^{89}$ We give $Y$ credit for snatching the cup away from her husband, but we have no basis for reassessing $X$ 's blaineworthiness when his wife spits out the coffee. ${ }^{90}$

Thus we do think that, other things being equal, the atteinpter who abandons is a less blaineworthy person than the attempter who does not. But our reassessinent is not that $Y$ is in no way a blaineworthy person. The clami must be that her lesser blameworthiness is grounds for a defense to atteinpt, and it is uncertain why that should follow. The arguinent, moreover, takes a faulty view of criminal hability. The prohibitions of criminal law are concerned with culpable conduct, but not with a kind of personal blameworthiness that goes beyond blameworthiness for engaging in such conduct. ${ }^{91}$ Were that the concern, we would be committed to an investigation into $Y$ 's blameworthiness that would have to include far inore than her abandoned atteinpt, for there is virtually no limit to relevant evidence of personal blameworthiness. ${ }^{92}$

A final version of the culpability argument is that punishment of atteinpters who abandon serves no purpose. One writer says that if an attempter abandoned "because he realized that what he was doing was

views if we were concerned with the defendant's blameworthiness as a person. In Part IV, I will suggest how these post-crime events are properly taken into account in making criminalization decisions.

89. See P. Winch, Trying, in ETHics AND ACTION 130, 144-50 (1972); Silber, Being and Doing: A Study of Status Responsibility and Voluntary Responsibility, 35 U. CH1. L. REV. 47, 79 (1967).

90. See Silber, supra note 89 , at $76-80$.

91. Cf. S. Benn \& R. Peters, The Principles of Political Thought 205 (1965) (published originally as Social Principles AND THE Democratic STate (1959)) ("[W]e do not punish men for their wickedness, but for particular breaches of law. . . . We may have to answer for our characters on the Day of Judgment, but not at Quarter Sessions.").

92. We might spin out the cases of $X$ and $Y$ at great length. Suppose, for example, that when his wife spits out the coffee, $X$ has a feeling of happy relief that his plan has failed. $C f$. Silber, supra note 89 , at $75-76,79$. He may also realize that he has done a terrible thing by trying to kill his wife; he may then have a real "change of heart" and "thank God that he failed." P. WiNCH, supra note 89 , at 144 . In contrast, suppose that $Y$, after snatching the cup from her husband, immediately feels angry with herself for not carrying through with her plan. $C f$. Silber, supra note 89, at 75-76. She may continue to regret that she did not kill her husband, resolving to do so at the earliest opportunity. As the post-attempt activities of $X$ and $Y$ proceed in these directions, at some point our reassessment of $Y$ 's blameworthiness as a person will put her on a par with (or even below) $X$. (Nor can we ignore the pre-attempt activities of $X$ and $Y$, but let this suffice.) 
wrong, and if the realization has a lasting effect, then punishment based on reformation or deterrence is superfluous." A3 Another asks: "If a person is truly repentant and has caused no harm, what is the point in punishing him?"94 A sufficient reply is that such questions should be answered in a particularized inquiry after conviction. If the purposes of punishunent will be served madequately or not at all, the attempter who abandons can be sentenced accordmgly. ${ }^{95}$ Thus, such an argument cannot show that abandonment should be a defense.

\section{Requirements of the Defense}

I have argued that attempt hability should not be imposed on those who, havimg abandoned their efforts, did not try to commit crimes. The requirements of the defense follow from my argument. Because nearly all abandonment provisions in this country track the Model Penal Code formulation of the defense, I will use that formulation as a vehicle for explaining what should count as a valid abandonment.

\section{The Model Penal Code Formulation of the Defense}

Opponents of the defense sometimes charge that it would be too broad. Stephen, for mstance, worried that it would acquit one who "voluntarily" abandoned an attempt "because he encountered more resistance than he expected, or ... because he was or thought he was discovered."96 The answer of the Model Penal Code drafters is the usual one: such attempters have "involuntarily" abandoned and thus are not within the defense. ${ }^{97}$ To capture this distmction the drafters proposed, in a tentative draft, the requirement that the defendant abandon "under circumstances manifestimg renunciation of his criminal purpose." proposed requirement was meant to embody two elements: first, that "abandonment of the criminal effort originate with the actor and not be forced upon him by some external circumstance such as police interven-

93. Rotenberg, Withdrawal as a Defense to Relational Crimes, 1962 Wis. L. REv. 596, 599.

94. Garton, The Actus Reus in Criminal Attempts, 2 QuEEN's L.J. 183, 215 (1974) (emphasis deleted). Garton answers that there is no point: "Factors such as deterrence, prevention and reformation cease to be relevant." Id.; accord R. CROSS \& P. JONES, AN INTRODUCTION TO Criminal LAw 367 (R. Card 9th ed. 1980); Stuart, supra note 9, at 521; Sullivan, Crossing the Rubicon in Miami, 41 MOD. L. REV. 215, 218 n.23 (1978).

95. This is often the view of those who reject the defense. See, e.g., Gledhill, "Attempt" in Indian Criminal Law, 4 INDIAN Y.B. INT'L AFF. 304, 307 (1955); Skilton, supra note 1, at 311 n. 4; Wasik, supra note 87 , at 795 . In jurisdictions not recognizing the defense, appellate courts have occasionally directed that the defendant's abandonment be considered at sentencing. See People v. Brown, 90 Ill. App. 3d 742, 750-51, 414 N.E.2d 475, 482 (1980); State v. Parish, 405 So. 2d 1080, 1088 (La. 1981) (plurality opinion).

96. 2 J.F. STEPHEN, supra note 6, at 227; see Mueller, The German Draft Criminal Code 1960. An Evaluation in Terms of American Criminal Law, 1961 U. ILL. L.F. 25, 58-59.

97. See, eg., D. STUART, supra note 11, at 542-43; Ryu, supra note 70, at 1199 .

98. Model Penal Code $\S 5.01(4)$ (Tent. Draft No. 10, 1960). 
tion," and second, that "abandonment be permanent and complete rather than temporary or contingent."

It was suggested at a meeting of the American Law Institute, however, that the proposed requirement would allow the defense to defendants the drafters wished to exclude. ${ }^{100}$ As a result, the drafters modified the provision to require that the defendant abandon "under circumstances manifesting a complete and voluntary renunciation of his criminal purpose."101 They also added a new paragraph defining these terms:

[1] [R]enunciation of criminal purpose is not voluntary if it is motivated, in whole or in part, by circumstances, not present or apparent at the inception of the actor's course of conduct,

[a] which increase the probability of detection or apprehension or

[b] which make more difficult the accomplishment of the criminal purpose.

[2] Renunciation is not complete if it is motivated by a decision [a] to postpone the criminal conduct until a more advantageous time or

[b] to transfer the criminal effort to another but similar objective or victim. ${ }^{102}$

By requiring "complete and voluntary renunciation," as defined, the drafters intended to make explicit the two elements they said were implicit in the original renunciation requirement. ${ }^{103}$

This formulation allows the defense in the clearest cases of valid abandonment. If, for example, the defendant discontimued an attempted rape "because he realized that what he was doing was wrong"104 or an attempted burglary because "'[he] didn't want to go through with it," "105 then the defendant's motive would not be among those specified in the negative definitions of "voluntary" and "complete." 106 But when

99. Id. $\$ 5.01$ comment at 71 .

100. Discussion of the Model Penal Code, 37 A.L.I. Proc. 80, 151-57 (1961).

101. Model Penal Code § 5.01(4) (Proposed Official Draft 1962).

102. Id. (I have subdivided and arranged the paragraph for the sake of clarity.)

Virtually identical definitions appear in ALASKA STAT. § 11.81.900(b)(49)(A)-(B) (1983 \& Supp. 1985); AM. SAMOA CODE ANN. $§ 46.3403$ (1981); ARIz. Rev. STAT. ANN. $§ 13-1005$ (C) (1978); Colo. Rev. Stat. § 18-2-401 (1978); Conn. Gen. STat. ANN. \& 53a-50 (West 1985); Del. Code ANN. tit. 11 , § 541(c) (1979); GA. CODE ANN. § 26-1003 (1983); 9 GUAM CODE ANN. § 7.73(d) (1983); HAWAII Rev. STAT. § 705-530(4) (1976); Ky. Rev. STAT. ANN. § 506.020(2) (Bobbs-Merrill 1985); ME. Rev. STAT. ANN. tit. 17-A, § 154(2)(C) (1983); N.H. Rev. STAT. ANN. § 629:1(III) (1974); N.J. Stat. ANN. § 2C:5-1(d) (West 1982); N.Y. Penal LaW § 40.10(5) (McKinney 1975); N.D. Cent. Code $\S 12.1-06-05(3)(c)$ (1985); 18 PA. Cons. Stat. AnN. § 901(c)(2) (Purdon 1983); TeX. Penal CODE ANN. § 15.04(c) (Vernon 1974); Wyo. STAT. § 6-1-301(b) (1983).

103. See Wechsler, Jones \& Korn, The Treatment of Inchoate Crimes in the Model Penal Code of the American Law Institute: Attempt, Solicitation, and Conspiracy, 61 CoLUM. L. REV. 571, 61617 (1961).

104. State v. Lammers, 29 Or. App. 207, 209, 562 P.2d 1223, 1224 (1977).

105. Wheelis v. State, 340 So. 2d 950, 951 (Fla. Dist. Ct. App. 1976).

106. Other examples mclude a defendant discontinuing an attempted murder because "he was 
the defendant's motive for discontinuance is among those specified, the Model Penal Code formulation is too restrictive.

\section{a. The Voluntariness Requirement: Risks and Difficulties}

The Model Penal Code voluntariness requirement bars the defense whenever increased risks or difficulties motivate defendants to discontinue. But the defense should be denied to such defendants only when they have tried and failed to commit crimes, since otherwise they are unjustifiably subject to attenipt hability. Both parts of the voluntariness requirement are therefore too restrictive.

The part I have marked as [1][a] denies the defense to defendants "motivated ... by circumstances ... which increase the probability of detection or apprehension."107 In the typical situation, the defendant's discontinuance follows the (anticipated) appearance of law enforceinent agents. ${ }^{108}$ For example, in a Colorado case a witness, observing two inen trying to break into a building, notified police officers who "ran across the parking lot and proniptly apprehended and arrested" the suspects as they "were walking hurriedly away." 109 The court reversed a ruling that the defense was established as a matter of law, holding that the jury could infer that "the defendant was leaving the scene of the crine because he and his partner had been detected and police officers were in view." "10 In an attempted-burglary case, the Minnesota Suprenie Court denied the defense on the ground that "the jury could infer the burglars had been frightened by the sound of the constable's approaching automo-

struck with remorse," State v. Henry, 128 Ariz. 204, 206, 624 P.2d 882, 884 (1980), an attempted prison escape " "because I thought of my family," " Commonwealth v. McCloskey, $234 \mathrm{~Pa}$. Super. 577, 579, 341 A.2d 500, 501 (1975), an attempted arson because " 'God . . . stayed my hand," " People v. Graham, 176 A.D. 38, 39, 162 N.Y.S. 334, 334 (1916), or because a " "still, small voice' ... bade him desist," Weaver v. State, $116 \mathrm{Ga}$. 550, 554, 42 S.E. 745, 747 (1902), an attempted burglary because "he got 'scared," " People v. Brown, 90 Ill. App. 3d 742, 744, 414 N.E.2d 475, 477 (1980), or an attempted robbery because "[he could not] summon the "courage," " State v. Workman, 90 Wash. $2 d 443,446,584$ P.2d 382, 384-85 (1978). Of course the defense will almost always raise a jury question. See, e.g., People v. Nassar, 59 Misc. 2d 1034, 1039, 301 N.Y.S.2d 671, 677 (1969) ("Basically, renunciation is a trial jury question and not one of law. It involves close questions of fact, turning on credibility of witnesses, and such weighing of credibility is traditionally considered to be within the jnry's peculiar competence.").

107. See supra text accompanying note 102 .

108. Private parties, of course, may also account for the risk of detection or apprehension. See State v. Cox, 278 N.W.2d 62, 66 (Minn. 1979) (defendant feared that noise might attract attention, preventing murder scheme from succeeding); Commonwealth v. Martin, 307 Pa. Super. 118, 121-22, 127, 452 A.2d 1066, 1068, 1070-71 (1982) (where defendant discontinued attempted rape when victim "faked an asthma attack and when her wheezing kept getting louder and louder," factfinder could infer that defendant did so "out of fear of detection"); Garcia v. State, 630 S.W.2d 914, 916-17 (Tex. Crim. App. 1982) (where defendant's attempted rape "ended when [he] noticed a car approaching," no instruction on defense because he "acted to avoid detection and apprehension").

109. People v. Traubert, 625 P.2d 991, 992 (Colo. 1981).

110. Id. at 993 . 
bile" and thus that the defendant "did not attempt to withdraw before discovering his apprehension was imminent." 111 In New York, an attempted-larceny indictment was upheld because there was evidence that the defendant's discontimuance "was motivated by the suspicion that the authorities had been alerted and that he was im imminent danger of apprehension if he pursued the matter." 112

The flaw in requirement [1][a] is the misconception of the significance of the operative motivation in such cases-the increased probability of detection or apprehension. In specifying this motive of increased risk, the Model Penal Code drafters intended to distinguish between fear of the law reflected in a general "reappraisal by the actor of the criminal sanctions hanging over his conduct," which satisfies the requirement, and "fear of the law [that] is . . related to a particular threat of apprehension or detection," which does not. ${ }^{113}$ This distinction misses the point. Fear of a particular threat of detection or apprehension is relevant to the defense only as a way of showing that the defendant tried and failed to commit a crime.

The significance of increased risk is that it may be the practical equivalent of prevention by outside interference. Suppose my goal was to bring about prohibited state of affairs $A$ and I engaged in conduct otherwise sufficient for atteinpt hability. If I thought I would not succeed in bringing about $A$ because I discovered that my apprehension was imminent, and I therefore discontinued my effort, then my discontinuance was indeed "forced upon [me] by some external circuinstance such as pohice intervention."114 Hence, I tried and failed to bring about $A$ and should not be entitled to the defense. Suppose, however, thinking I could still succeed, I nevertheless discontinued because of a particular threat of apprehension or detection. Then I did not try to bring about $A$, for I did not continue acting towards my goal to the extent that I could. I should therefore be entitled to the defense. ${ }^{115}$ Consequently, the requirement

111. State v. Hansen, 290 Minn. 552, 553, 188 N.W.2d 881, 881-82 (1971) (per curiam).

112. People v. Bauer, 43 A.D.2d 833, 833-34, 350 N.Y.S.2d 745, 746 (1974) (per curiam); see also Commonwealth v. Howard, $248 \mathrm{~Pa}$. Super. 246, 253, 375 A.2d 79, 83 (1977) (affirming conviction where defendant discontinued attempted escape "only after being discovered by one of the prison guards").

113. Model Penal Code $\S 5.01$ comment at 70 (Tent. Draft No. 10, 1960).

114. Id. at 71 ; see W. LAFAve \& A. Scort, supra note $16, \S 60$, at 448 (no defense when defendant discontinues "because he thinks that his scheme... would be thwarted by police observed in the area of the intended crime" (footnote omitted)).

115. See J. Andenaes, The General Part of the Criminal Law of Norway 300 (T. Ogle trans. 1965) (discussing Norwegian PENAL CoDe § 50) ("[T] he condition for impunity is that he gives up the attempt even though he knows that he could have achieved his goal by continuing."); Oehler, Attempted Crimes, 24 AM. J. CoMP. L. 694, 701 (1976) (discussing STGB art. 24 (W. Ger.)) (" $[\mathrm{I}] \mathrm{t}$ is of no importance whether it is repentance or the fear of being discovered or punished which induces the perpetrator to change his mind.... Only if he fears discovery and thinks that the completion of the crime is impossible is voluntary withdrawal out of the question."). 
that the defendant not be motivated by the increased probability of detection or apprehension is too restrictive, because a defendant so motivated may not have tried to commit a crime.

The second part of the voluntariness requirement, which I have marked as $[1][\mathrm{b}]$, demies the defense to defendants "motivated . . . by circumstances ... which make more difficult the accomphshment of the criminal purpose."116 In a Pennsylvania case, for example, the defendant was convicted of attempted burglary for his effort to pry open the secured wimdow screen of an apartment. He claimed the defense, but the court rephed that the jury could infer that he discontinued "because the window screen was more difficult to unfasten than he had anticipated."117 A Texas court rejected the defense in an attempted-rape case on evidence that the defendant grabbed the victim in the laundromat of an apartinent complex, that she began struggling with him as he tried to remove her clothes, that "[t]he struggle continued as the [victim] moved out the door of the laundromat and into the parking lot of the complex," that he "had his hand over her mouth," and that "[a]fter she bit his finger, [he] released [her] and . . . drove away in a car." 118

The flaw in requirement [1][b], like that in requirement [1][a], is the misconception of the significance of the operative motivation in such cases. It is proper to exclude the defendant who discontinues an effort "because his powers or instruments are madequate for completing the crime." 119 Would-be rapists physically unable to succeed ${ }^{120}$ and wouldbe burglars whose tools were ineffective ${ }^{121}$ have tried and failed to commit crimes and should not be entitled to the defense. But requirement [1][b] is not limited to such defendants. In the Pennsylvania case mentioned above, for example, the defendant, who discontinued because committing the burglary "was more difficult . . . than he had anticipated," 122 may yet have been able to complete the crime. If so, then unless the difficulties he encountered show that he tried and failed, denying him the defense imposes unjustified liability.

The significance of difficult circumstances is that they may show that the defendant had practically no choice but to discontinue the effort to commit the crime. Suppose my goal is to bring about prohibited state

116. See supra text accompanying note 102.

117. Commonwealth v. Herman, 271 Pa. Super. 145, 152 n.7, 412 A.2d 617, 620 n.7 (1979).

118. Hackbarth v. State, 617 S.W.2d 944, 945-46 (Tex. Crim. App. 1981); see also Haight v. State, 654 P.2d 1232, 1242 (Wyo. 1982) ("We do not think a voluntary ... . renunciation can ever rest on the fact that a criminal desists from his attempt partially because his intended victim is resisting more than he might have anticipated.").

119. Model Penal Code $\S 5.01$ comment at 69 (Tent. Draft No. 10, 1960) (footnote omitted).

120. E.g., Guthrie v. State, 147 Ga. App. 351, 352, 357, 248 S.E.2d 714, 717, 719 (1978).

121. E.g., State v. Radi, 168 Mont. 320, 324, 542 P.2d 1206, 1209 (1975) (jury eould conclude that defendants discontinued attempted burglary because they "found their efforts to be futile").

122. Commonwealth v. Herman, 271 Pa. Super. 145, 152 n.7, 412 A.2d 617, 620 n.7 (1979). 
of affairs $A$ but I am confronted with increased or unexpected difficulties in the course of iny effort. If I continue insofar as I can, until I reach the point where things become "just too difficult," 123 and I therefore discontinue my effort, then I have tried and failed to bring about $A$ and should not be entitled to the defense. The would-be rapist in the Texas case provides a good illustration. ${ }^{124}$ On the other hand, suppose that I am confronted with increased or unexpected difficulties but that I do not continue in my effort to the extent that I can. In that case, even if I discontinued because of those difficulties, neither I nor anyone else who appraises my conduct in relation to iny goal can say that I tried to bring about $A .^{125}$ I should therefore be entitled to the defense. ${ }^{126}$ Agam, the second part of the voluntariness requirement is too restrictive, because a defendant inotivated to discontinue by increased difficulties inay not have tried to commit a crime.

\section{b. The Completeness Requirement: Postponement and Transfer}

The Model Penal Code formulation also requires a "complete" abandonment. ${ }^{127}$ This requirement denies the defense to defendants whose inotive in discontinuing is either to postpone commission of the crime until a better time or to transfer their efforts to other, similar targets. But the first part of this requirement is unnecessary, and the second part adds ouly unjustified hability.

The part I have marked as [2][a] denies the defense to defendants "motivated by a decision to postpone the criminal conduct until a inore

123. Jones, supra note 63 , at 374 :

It is a different case if I find half-way through on my journey from $A$ to $B$ that $I$ cannot proceed further-the line has been blocked and there is no other way, or I have suffered a heart attack, or things have become just too difficult. Such are the circumstances in which I can be said to have tried to get from $A$ to $B$, and failed.

124. See supra text accompanying note 118 .

125. "[T]rying necessarily involves a kind of inaking sure that you know you cannot do what you said you would try to do, before you give up." Broadie, supra note 63, at 35 .

126. See J. Andenaes, supra note 115, at 300 (discussing Norwegian Penal Code $\S 50$ ) (The defense is not necessarily precluded when the attempt is discontinued because the defendant "realizes that ... the difficulties [are] greater than he had expected. A man who abandons a rape attelnpt when he discovers that the woman offers serious opposition will nevertheless obtain inpunity if he thought he might have been able to attain his purpose despite the opposition.").

127. At the American Law Institute meeting referred to supra text accoinpanying note 100, the Reporter insisted on the need for "a larger renunciation than a determination that the moment is unpropitious." The response: "You don't mcan he has to reform forever, do you? . . That is asking too much." The Reporter agreed that "[f]orever is too inuch," but asserted that "beyond the conclusion that the particular moment is unpropitious is not too much." Discussion of the Model Penal Code, supra note 100, at 152. As the Reporter later explained, the definition of "complete" is meant to exclude a defendant who decides "to wait for a better opportunity to commit the crime," but not to "inpose on the defendant the impossible burden of proving that henceforth his conduct will be lawful." Wechsler, Jones \& Korn, supra note 103, at 617. But see Kelman, supra note 85, at 630 (assuming that there are only two possibilities: "moving on to a more advantageous time and place" and "abandoning a life of criıne"). 
advantageous time." 128 For example, a Colorado defendant was convicted of attempted burglary on evidence that he rode a bicycle up the driveway to a house, broke a window, and shortly thereafter rode back down the driveway and away; the police found him two blocks north of the louse, heading soutli. The conviction was reversed, the court holding that the jury sliould have been instructed on the defense. ${ }^{129}$ Suppose, on retrial, the jury finds that the defendant, not motivated by the discovery of mcreased risks or difficulties, was nevertheless "temporarily postponing the crime." 130 If so, requirement [2][a] denies him the defense. The result is correct, but for a different reason, as a slight variation of the facts will sliow.

Had the defendant, before appreliension, returued and committed the burglary, it would be wrong to say that lie made two successive efforts to achieve his goal, the first of which he discontinued before embarking on the second. He would have inade but one, drawn-out effort to commit a burglary (in which he succeeded). ${ }^{131}$ The point applies here. Having decided to postpone commission of the crime, the defendant did not discontinue the effort to achieve his goal. When we appraise his conduct in relation to that goal, we conclude that he tried and failed to commit a burglary. Nor slould he be entitled to the defense under the Model Penal Code provision, wholly apart from requirement [2][a]. A defendant is eligible for the defense only if "he abandoned his effort to commit the crime."132 Since defendants who merely postpone commission of crimes lave not discontinued their efforts, they are ineligible for the defense. Requirement [2][a] is superfluous.

The remaining part of the formulation, which I have inarked as [2][b], denies the defense to defendants "motivated by a decision . . . to

128. See supra text accompanying note 102. Ordinarily a decision to postpone commission of a crime is based on the discovery of increased risks or difficulties. For example, two Ohio defendants planned to rob a store; one climbed onto the roof of the store while the other stayed on the street as a lookout; the former climbed back down after hearing a nearby fire engine siren; and they walked away, leaving their car parked near the store. State v. Woods, 48 Ohio St. 2d 127, 130-31, 357 N.E.2d 1059, 1062-63 (1970). The court rejected the claim that the defense had been established, noting that the purported discontinuance was neither voluntary ("[a]bandoning an attempt out of fear that the police might be coming") nor complete, since the jury could "infer that they intended only to wait at a distance and observe whetler the robbery might still be possible despite the siren they had heard." Id. at 133, 357 N.E.2d at 1064 (footnote omitted).

129. People v. Johnson, 41 Colo. App. 220, 221-22, 585 P.2d 306, 307-08 (1978).

130. Id. at $221,585 \mathrm{P} .2 \mathrm{~d}$ at $307-08$.

131. If we say that the defendant made two separate efforts to commit burglary, then he should be liable for two crimes. For if he discontinued the first effort, then the atteinpted burglary (for which, under requirement [2][a], he would have no defense) was independent of the completed burglary. Hence, the rule barring conviction for both atteinpt and the crime attempted, ModeL PENAL CODE $\$ 1.07(1)(a)$, (4)(b) (Proposed Official Draft 1962), would not apply. Requirement [2][a], by presupposing that a defendant who postpones has discontinued, suggests this incorrect view.

132. Id. $§ 5.01(4)$. 
transfer the criminal effort to another but similar objective or victim."133 The Model Penal Code drafters envisioned a would-be robber who decides that his intended victim, $X$, "who he thought would be easy pickings, is actually going to be a tough fellow to handle. So instead of going ahead with the idea of robbing $X$, at the last minute he passes it up. But his object is to rob $\mathrm{Y}$ or $\operatorname{rob} \mathrm{Z}$, or somebody else." ${ }^{134}$ To avoid repeating the discussion of the voluntariness requireinent, let us vary the facts, so that what inotivates transfer is not the difficulty of robbing $X$ but the appearance of "a better opportumity"135 in the sense of a wealthier victim.

Suppose that while proceeding in an effort to rob $X$ you spot such a victim, $Y$; in order to rob $Y$, you discontinue your effort to rob $X$. Under requireinent [2][b], you are hable for the attempted robbery of $X$. But you should be entitled to the defense. For suppose that you did in fact rob $Y$. Under requirement [2][b], you will be hable both for the robbery of $Y$ and for the atteinpted robbery of $X$. Yet you did not, insofar as you could, continue in your effort to rob $X$-otherwise you would have robbed $X$ rather than $Y$. Whether you discontinued your effort to rob $X$ because you decided to rob $Y$ or because you decided to get $Y$ 's autograph, you did not try and fail to rob $X$. Atteinpt hability would therefore be unjustified. Because this will be so whenever a defendant (not inotivated by increased risks or difficulties) decides to transfer a criminal effort, requireinent [2][b] is unacceptable.

\section{What Counts as a Valid Abandonment}

Having assessed the Model Penal Code formulation in terms of my arguinent for the defense, I can now state in brief coinpass what conduct should count as a valid abandonment. The law should recognize the defense in order not to impose unjustified atteinpt hability on those who did not try to commit crimes. Those who discontinue their criminal efforts should be entitled to the defense, therefore, unless the conclusion is warranted that they nevertheless tried and failed to commit crimes.

To be eligible for the defense, a defendant inust in fact discontinue the criminal effort. ${ }^{136}$ Postponeinent is not discontinuance. ${ }^{137}$ Nor is refraining from further action necessarily discontinuance. If one sets

133. See supra text accompanying note 102.

134. Discussion of the Model Penal Code, supra note 100, at 154-55.

135. Model Penal Code $\$ 5.01$ comment at 69 (Tent. Draft No. 10, 1960).

136. Defendants in attempted murder cases have claimed that they discontinued their efforts after shooting (at) or stabbing (at) their victims. Courts interpreting abandonment provisions have held such defendants ineligible for the defense on the ground that the crime of attempt is already "complete." See Chaney v. State, 417 So. 2d 625 (Ala. Crim. App. 1982); McCowan v. State, 412 So. 2d 847 (Ala. Crim. App. 1982); State v. Smith, 409 N.E.2d 1199 (Ind. App. 1980). The Model Penal Code drafters agree. Model Penal Code $\S 5.01$ comment at 73 (Tent. Draft No. 10, 1960); 
forces in motion that would normally bring about the substantive crime (the bomb is set to go off, for example, but can still be disarmed), then one can discontimue the criminal effort only by taking action to prevent commission of the crime. ${ }^{138}$ Ordinarily, however, cessation of activity

see White, The Inchoate Crimes Provisions of the New Pennsylvania Penal Code, 35 U. P1TT. L. REV. 235, 241-42 (1973).

This interpretation rests on a inistake. Under these provisions, an attempt is not complete if thc defendant "abandoned his effort to commit the crime . . . under circumstances manifesting a complete and voluntary renunciation of his criminal purpose." MODEL PENAL CODE $\S 5.01(4)$ (Proposed Official Draft 1962). The issue in these cases is whether the defendant's "effort" was discontinued. The courts' inistake can be highlighted effectively in a situation where the defendant is eventually successful.

Suppose your goal is to shoot and kill $V$. You fire three shots: the first misses, the second wounds, and the third kills $V$. If firing a shot necessarily means that an attempt is complete, then it follows that you made three separate efforts to kill $V$, two of which failed and one of which succeeded, and you should therefore be liable for three crimes: (1) attempted inurder, (2) atteinptcd murder, and (3) inurder. That may be the correct conclusion in unusual cases (perhaps you fired the shots at inonthly intervals), but in any ordinary case it is incorrect. Although you fired more than once, your actions ordmarily would constitute but one effort to achieve your goal of killing $V$. Consequently, if after firing and missing or wounding you fire again and kill, you should be liable for murder but not botli for inurder and for atteinpted murder. And if instead you decide not to fire again, then you have discontinued your effort to commit the crime and should be eligible for the defense. (If you wound, however, you may have to take further action to prevent $V$ 's death. See infra note 138 and accompanying text.)

Two additional points should be noted. First, being eligible for the defense is not equivalent to being entitled to it. If, for exainple, you discontinued your effort because $V$ was responding in kind and you feared for your life, then you tried and failed to commit the crine and should not be entitled to the defense. Sccond, the abandoninent defense to attempt does not preclude independent criminal liability in these cases for engaging in dangerous conduct or for actually causing harm. Thus, a defendant inay have an abandoninent defense to attempted inurder, but still be liable for, say, assault with a deadly weapon. See infra note 144.

137. See supra text accoinpanying notes 131-32.

138. See Model Penal Code $\S 5.03$ cominent at 144 (Tent. Draft No. 10, 1960). The Model Penal Code provision is too restrictive in this respect. A defendant is eligible for the defense only if "he abandoned his effort to cominit the crime or otherwise prevented its commission." MODEL PeNal CoDE $\S 5.01(4)$ (Proposed Official Draft 1962). It may happen, however, that the defendant seeks to prevent commission of the crime, but is unsuccessful because the crime is prevented in some other fashion. See, e.g., People v. Grant, 105 Cal. App. 2d 347, 349-51, 233 P.2d 660, 662-63 (1951) (defendant sought to retrieve suitcase containing bomb set to go off after departure of airplane, but boinb exploded while airplane was on ground and before defendant arrived); Harkey v. State, 90 Tex. Crim. 212, 213-14, 234 S.W. 221, 222-23 (1921) (defendant sought to retrieve poisoned coffee grounds, but they had already been thrown out). In two jurisdictions, the defense is available in such cases if the defendant "made a reasonable effort to prevent tlie . . . result which is the object of the atteinpt.” AR1Z. REV. STAT. ANN. § 13-1005(A) (1978); HAWAll REV. STAT. § 705-530(1) (1976); cf. Tex. Penal Code ANN. $\$ 15.04$ (d) (Vernon 1974) (penalty reduced one grade if defendant "Inade substantial effort to prevent the cominission of the object offense"). The defense is similarly available under many foreign codes. See, e.g., STGB art. 16(2) (Aus.); ThE DANiSH CRiminaL CODE $\S 22$ (E. Giersing trans. 1958); C.P. art. 24(2) (Port.); STGB art. 24(1) (W. Ger.). Under the Model Penal Code provision, however, such defendants, not themselves having prevented commission of the substantive crimes, are ineligible for the defense. This erroneous exclusion should be correeted. The availability of the defense should not turn on whether the defendant is the one who prevents cominission of the crime. Of course, if the crime is actually committed, the defendant's substantive liability will depend on the requirements of the crime. 
towards the criminal goal constitutes discontinuance of effort. Such defendants are ehigible for the defense.

In the absence of risks or difficulties, discontinuance, for whatever reason, is a valid abandonment. For if you easily could have achieved your criminal goal-if, say, you had the victim at your mercy ${ }^{139}$-but did not do so, then you did not try to aclieve that goal. Discontinuance because of risks or difficulties, however, is not always a vahid abandonment. If circumstances inade continuance of your criminal effort so risky or difficult that you were practically forced to discontinue, then you tried to coinmit a crime and are justifiably subject to attempt liability. ${ }^{140}$ You need not have done everything possible to succeed; you may have tried and failed even though conceivably you could have tried harder. ${ }^{141}$ But you must have continued, despite the risks or difficulties, to the extent that you could. If you discontinued because of risks or difficulties without having continued in your effort insofar as you could, then you did not try to commit a crime. Your discontinuance is a vahid abandonment. ${ }^{142}$

The determinative question, then, is whether the defendant, though having discontinued a criminal effort, nevertheless tried to commit a criine. To complete this discussion, I will examine several situations that have been thought to raise tricky issues of abandonment. ${ }^{143}$

First is the situation where the defendant is disappointed to discover that the fruits of the intended crime are less than anticipated. In a New York case, for exainple, the defendant and a cohort entered a gas station and deinanded money. "When the station attendant produced only about $\$ 50$ and affirmed that this was all the cash available, the inan holding the gun stated, 'I was just kidding, forget it ever happened,' and the two inen departed." 144 If the defendant discontinued the effort

139. For example, a Georgia defendant was convicted of kidnapping the victim and then raping her twice, but acquitted of attempted sodoiny. The court rejected his claim of inconsistent verdicts: "Although the victim's testimony ... would have supported a conviction for attempted aggravated sodomy, it did not demand it. The jury may well have believed all of her testimony and still have determined that the defeudant ... abandoned his effort . . ." Stewart v. State, 147 Ga. App. 547, 548, 249 S.E.2d 351, 352 (1978).

140. See supra text accompanying notes $114 \& 123-24$.

141. See supra note 68 and text accompanying notes $66-68$.

142. See supra text accompanying notes $115 \& 125-26$.

143. Professor Fletcher refers to them as "subtle borderline cases." G. FLETCHER, supra note $35, \S 3.3 .8$, at 191 .

144. People v. Johnston, 87 A.D.2d 703, 703, 448 N.Y.S.2d 902, 902-03 (1982). The defendant, convicted of attempted robbery, complained that the trial judge had refused to instruct on the lesser included offense of menacing. The court affirmed: "Renunciation does not negate the commission of the inchoate crime of atteinpt. . . . Under no reasonable view of the evidence could the jury have found that [the defendant's actions] constituted menacing and not attempted robbery." Id. at 704, 448 N.Y.S.2d at 903-04. This statement reflects a misunderstanding of the abandonment defense. Assumiug that the defendant's conduct (before discontinuance) constituted both menacing and attempted robbery, theu, if the jury accepted the defense, the defendant would not be liable for attempt but would (and should) be liable for menacing. For an example of the correct approach in 
because he thought $\$ 50$ was not enough money, then he did not try and fail to commit robbery and should be entitled to the defense. ${ }^{145}$

There is also the situation where someone persuades the defendant to discontinue. In a German case, the defendant's partner persuaded him not to go through with a burglary. ${ }^{146}$ In a New York case, the two defendants discontinued their effort to steal a bicycle following a brief discussion with a bystander. ${ }^{147}$ An Oregon defendant claimed that he discontinued his effort to rape the victim because she persuaded him to stop. ${ }^{148}$ The defendants should be entitled to the defense in these persuasion cases. It is irrelevant what the persuader said or whether the persuader was an accomplice, an outsider, or a victim. The defendants did not continue in their efforts insofar as they could, but, having been persuaded to change their minds, simply decided not to commit their intended crimes.

Finally, there is the situation where the defendant may be described as "losing interest" in the crime. Professor Fletcher discusses a German case denying the defense to a defendant who discontinued an attempted rape because the victim was menstruating. ${ }^{149}$ Fletcher agrees that the

this kind of situation, see People v. Johnson, 41 Colo. App. 220, 222, 585 P.2d 306, 308 (1978) (abandonment defense available to charge of attempted burglary, but not to charge of criminal mischief for breaking window in order to gain entry).

145. Fletcher suggests that a disappointed robber eould be denied the defense "by defining his activity as the attempt to steal at least [\$50], which turned out to be impossible under the circumstances." G. FLETCHER, supra note 35, § 3.3.8, at 191-92 (footnote omitted). But suppose the defendant, after discovering that the victim has less than $\$ 50$, takes the money anyway. On this suggestion, the defendant would be liable both for attempted robbery (of at least $\$ 50$ ) and for robbery (of less than \$50). Perhaps that is conceivable. Suppose your goal is solely to steal a certain valuable art object, which turns out to be impossible because a cheap imitation has been put in its place. If you then decide to take the imitation, we might say that you tried and failed to achieve onc goal and thereafter succeeded in achieving another goal. You would thus be liable both for attempted theft (of the valuable objeet) and for theft (of the imitation). But in ordinary cases of disappointenent, the defendants do not have such highly particularized goals. It is not trnc in such cases that, had the defendants gone though with their crimes, we would or should hold them liable both for attempt and for the substantive crine. Hence, when these disappointed defendants discontinue, they should be entitled to the defense.

146. Id. at 194. The court allowed the defense. Id.

147. People v. Vasquez, 80 Misc. 2d 21, 362 N.Y.S.2d 333 (1974). The defendants, charged with attempted larceny, raised the defense, and the jury acquitted them. Id.

148. State v. Wasson, 45 Or. App. 169, 171 n.2, 607 P.2d 792, 794 n.2 (1980). The conviction was reversed because of the admission of evidence prejudicial to the defendant's abandonment defense. Id. at 173, 607 P.2d at 794-95. Similar fact situations have arisen in jurisdictions not recognizing the defense. See People v. Crary, 265 Cal. App. 2d 534, 539, 71 Cal. Rptr. 457, 460 (1968) (jury could find that defendants discontinued effort to rob gas station after attendant "talked to them in a fatherly fashion"); State v. Schmidt, 213 Neb. 126, 132, 327 N.W.2d 624, 628 (1982) (defendant discontinued effort to kill his wife "only because of [her] pleading and prounises").

149. G. FLETCHER, supra note $35, \S 3.3 .8$, at 194 . For similar attempted rape cases in jurisdictions not recognizing the defense, see People v. Westmire, 71 Cal. App. 2d 432, 162 P.2d 988 (1945) (victim was inenstruating); People v. Hamil, 20 Ill. App. 3d 901, 314 N.E.2d 251 (1974) (victim was a virgin); Le Barron v. State, 32 Wis. 2d 294, 145 N.W.2d 79 (1966) (victim was pregnant). The suggestion about the disappointed robber, supra note 145 , might also be made about 
defense should be denied: "That the defendant lost interest in carrying out the rape implied that he was no longer acting as the 'nuaster of his decision.' He revealed no strength of will in desisting, for he had no desire to carry through."150 Fletcher also agrees with another German case allowing the defense to a defendant who discontinued an attempted rape because of the victim's persuasion. ${ }^{151}$ There is, he says, a "philosophically defensible" distinction between these cases, "for there is a difference between being persuaded to give up one's criminal plan and being influenced by independent circuinstances to lose interest in the crime."152

For purposes of imposing justified atteinpt hability, these cases are indistinguishable. Defendants who discontinued their efforts because they "lost interest" in continuing, or because they had "no desire" to continue, necessarily did not continue in their efforts to the extent that they could. It is thus immaterial whether they were "influenced by independent circunistances" or by no identifiable circunistances at all. Likewise, defendants who discontinued their efforts because they were persuaded to give up their criminal plans did not continue insofar as they could. What matters is not why these defendants did not try to commit crimes; what matters is that they did not try.

\section{Response to Objections}

The case for the abandonment defense is not complete without consideration of possible objections. Some objections claim that recognition of the defense will have untoward consequences. These objections are best viewed as presenting "derivative" reasons for hability; they are not theinselves reasons for atteinpt hability, but given that we prohibit unabandoned attempts they inay be reasons for prohibiting abandoned atteinpts as well. In addition, the other-crimes objection claims that the crime of attempt does not differ from other crimes and thus should not have the supposedly special defense of abandonment.

\section{Concerns About Consequences}

Soine writers object that recognition of the defense will create a risk that defendants will escape attempt hability by falsely claiming abandonmient. $^{153}$ This objection-of the sort that can be made to any

these would-be rapists. (That is, the defense could be denied by characterizing the defendant's activity as the attempt to rape a nonmenstruating woman, which turued out to be impossible.) My response would be the same.

150. G. FleTCHER, supra note $35, \S 3.3 .8$, at 194 (footnote omitted).

151. Id. at 193.

152. Id. at 195 (footnote omitted).

153. See Wasik, supra note 87 , at 794; see also O. JENSEN, supra note 16, at 161 ; $c f$. Schillberg, $A$ Prosecutor's View of the Revised Washington Criminal Code, 48 WASH. L. REv. 133, 142 \& n.47 (1972) (arguing that defendant should bear burden of persuasion); Note, The Constitutionality of 
defense $^{154}$-is unpersuasive. For one thing, there is no reason to believe that the risk is more than minimal with the abandonment defense. ${ }^{155} \mathrm{But}$ the important point is that the rationale of attempt liability does not justify liability for abandoned attempts. To object to the defense on the ground that some guilty attempters might be acquitted is thus to maintain that we should prohibit abandoned atteinpts in order to avoid the risk of such erroneous acquittals. Without even evidence that the risk is substantial, this view is insupportable. ${ }^{156}$

It miglit be objected that recognition of the defense will weaken the educational and deterrent force of the criminal law, or at least the law of attempt, because of public misunderstanding of the defense and of acquittals in particular cases. ${ }^{157}$ This may be a legitimate concern with defenses that are excuses, like the insanity defense, where the defendant's conduct violates a criminal prohibition yet the defendant, because of special personal characteristics, is nevertheless not held criminally liable. ${ }^{158}$ But witli the abandonment defense this concern is misplaced. Abandonment is not an excuse for criminal conduct. Defendants acquitted on the

Affirmative Defenses After Patterson v. New York, 78 CoLuM. L. REv. 655, 677-78 (1978) (arguing that placing burden of persuasion on defendant is constitutional).

154. See H.L.A. HART, Prolegomenon to the Principles of Punishment, in PUnishmENT AND RESPONS1B1LITY 1, 19 (1968) ("Any increase in the number of conditions required to establish criminal liability increases the opportunity for deceiving courts or juries by the pretencc that some condition is not satisfied.").

155. See W. LAFAVE \& A. ScoTT, supra note $16, \S 60$, at 450 (risk that recognition of defensc will result in acceptance of false claims "seems slight"). The burden of production is placed on the defendant in all American jurisdictions recognizing the defense, and in many of them the burden of persuasion is as well. See 1 P. Robinson, Criminal LAw Defenses § 81(a), at 349-50 (1984).

156. As a practical matter, the principal function of the crime of attempt may be that it "afford[s] a general vehicle for plea bargaining." SPEC1AL COMM. OF THE MICH. STATE BAR FOR the Revision of the CRIMINAL Code \& CoMm. ON CRIMINAL JuRISPRUdence, MichigaN REvised CRIMINal Code $\S 1001$ comment at 89 (Final Draft 1967); see 1 Working PaPers of the National Commission on Reform of Federal Criminal Laws 365 n.34 (1970) (reporting desire of sone federal prosecutors "that attempt be made generally a lesser included offense to allow for plea bargaining") [hereinafter cited as WORKING PAPERS OF THE NATIONAL Commission]. Those who think of attenipt in this way might object that recognition of the abandonment defense will weaken the prosecution's position in the bargaining process. See E. MEEHAN, supra note 9, at 226-27. It is doubtful that the objection has more force with this defense than with any other. But the important point, again, is that the prohibition of abandoned attempts is otherwise unjustified. It certainly cannot be justified as a means of strengthening the prosecution's bargaining position.

157. For a thorough discussion of the concern that recognizing defenses will undercut the purposes of criminal liability, see Robinson, Criminal Law Defenses: A Systematic Analysis, 82 Colum. L. Rev. 199, $244-50$ (1982); see also Dan-Cohen, Decision Rules and Conduct Rules: On Acoustic Separation in Criminal Law, 97 HARV. L. REv. 625, 633-34 (1984) (analyzing this concern in connection with duress defense as conflict between decision rule for courts and conduct rules defining offenses).

158. See Robinson, supra note 157, at 221, 246-49. "Excuses, for the most part, rely on subjective criteria like mental illness, mistake, or subnormality. Often only a person who is aware of the evidence adduced at trial will understand that acquittal is based upon these special characteristics of the actor, not on approval or tolerance of the act." Id. at 246 (footnote omitted). 
basis of abandonment have not been found to have violated a criminal prohibition. Since conduct that is within the defense is not criminally prohibited, the pubhic should not misunderstand the defense so as to undercut either the prohibition of atteinpts or criminal prohibitions in general. ${ }^{159}$ In any event, this unlikely possibility does not justify imposing otherwise unjustified hability for abandoned atteinpts. ${ }^{160}$

Finally, one might object that by recognizing the defense the law will be drawing an arbitrary line between atteinpters. Suppose that I abandoned and you were interrupted, so that I have a defense and you are hable for atteinpt. I would have been hable had I been interrupted instead, and, let us say, you would have abandoned had you not been interrupted when you were. Assuming that whether and when attempters are interrupted is a matter of luck or chance, it might seein that the difference between our cases is likewise a inatter of luck or chance. ${ }^{161}$ But since I abandoned and you did not, the difference is that standards of conduct are established to deal with what people do, not with what they would have done under other circumstances. ${ }^{162}$ That is not an arbitrary distinction.

159. In Professor Robinson's classification of defenses, the abandonment defense is an "offense modification." Id. at 210 \& n.36. Noting that "the conduct exculpated under an offense modification is not criminal," he concludes: "It seems more likely . . . that an acquittal under an offense modification will be viewed as it should, not as a repudiation of the offense definition, but as a refinement of it." Id. at 245.

160. A related objection is that recognition of the defense will directly encourage individuals to try to commit crimes. See Skilton, supra note 1, at 310 n.4. If we accept this claim, however, we should also accept the claim that the defense will encourage abandonment, and then the good and bad consequences may simply offset each other. See supra text aecompanying notes 70-75. At any rate, there is no reason to believe that the number of encouraged attempters will greatly exceed the number of attempters who abandon because of the defense. Thus, the possibility of more unabandoned attempts cannot justify the prohibition of abandoned attempts.

161. The role that luck or chance may play in attempt hability has been noted. See Glazebrook, Should We Have a Law of Attempted Crime?, 85 LAw Q. REv. 28, 43 (1969) (distinction between atteinpt and success "allow[s] chance to play an unnecessarily large part"); Temkin, Impossible Attempts-Another View, 39 MOD. L. REv. 55, 66 (1976) (defense of impossibility results in defendants' avoiding liability by luck or chance); cf. T. NAGEL, Moral Luck, in MoRTAL Questions 24, 25 (1979) ("Whether we succeed or fail in what we try to do nearly always depends to some extent on factors beyond our control."). See generally Smith, The Element of Chance in Criminal Liability, 1971 CRIM. L. REV. 63.

162. Nor is it relevant that attempters "who are interrupted ... are therefore deprived of the opportunity for voluntary abandonment." Ashworth, Sharpening the Subjective Element in Criminal Liability, ARCHIV FÜR RECHTS- UND SOZIALPHILOSOPHIE 79, 80 (Beiheft 19, 1984). All attempters are subject to the possibility of interruption before they abandon.

According to the California Supreme Court, on the other hand, recognition of the defense will deprive the police of the opportunity to make a timely interruption. Envisioning an "armed robber who feels a pang of conscience or chill of fear and bolts from the bank moments before the teller can hand over the loot," the court asserted: "Public safety would be needlessly jeopardized if the police were required to refrain from interceding until absolutely certain in each case that the criminal would go through with his plan." People v. Dillon, 34 Cal. 3d 441, 454, 668 P.2d 697, 702-03, 194 Cal. Rptr. 390, 396 (1983). But of course the defense does not require that the police give attempters time to abandon. 
Derivative reasons, then, do not justify liability for abandoned attempts. The only remaining challenge to the defense is the othercrimes objection.

\section{The Other-Crimes Objection}

A satisfactory argument for the defense must answer the objection that abandonment should not be a defense to attempt because repentance is not a defense to other crimes. Professor Fletcher states the othercrimes objection clearly:

In most systems it would be of no avail for a thief to argue that he returned the goods that he stole, or for someone who illegally possessed narcotics at one point of time to argue that he had thrown them away and therefore was no longer guilty. The offenses of larceny and possession are complete $m$ themselves and a subsequent change of heart is irrelevant to liability. If acts of repentance do not cancel liabihity for these offenses, wliy should an abandonment of an attempt constitute a reason for not convicting of the completed crime of attempt? ${ }^{163}$

That repentance is not in fact a defense to other crimes, however, has no necessary bearing on whether abandonment should be a defense to attempt. For the objection to be effective, it must assume both that repentance should not be a defense to other crimes and that repentance im relation to other crimes is equivalent to abandonment in relation to attempt. On these assumptions, the objection is that an argument for the abandonment defense to attempt is unacceptable if it is equally an argument for a repentance defense to other crimes. ${ }^{164}$

The objection can be met as follows. For any particular crime, such as larceny or illegal possession, we first have to determine whether one can engage im "acts of repentance" that are substantially equivalent to the abandonment of an attempt. Suppose that you are liable for attempted larceny, having been arrested during your attempt. After committing this crime, you might experience a change of heart. You might regret your wrongdoing and be sorry for what you had done; you might be so conscience-stricken that you undergo a spiritual rebirth that gives you a new character. But all this repentance would not affect your

163. G. FLETCHER, supra note $35, \S 3.3 .8$, at 186 . The other-crimes objection is an aspect of the traditional common law view of the defense. See supra note 1 and accompanying text.

164. Thus Fletcher attacks the reasons for the abandonmeut defense relied on by the Model Penal Code drafters, on the ground that they are also reasons for a repentance defense to larceny and illegal possession. G. FleTCHER, supra note $35, \S 3.3 .8$, at 186-87; see ALASKa CRIMINAL CODE Revision COMm'N, Preliminary RePORT \$ 39 comment at 129-30 (1976) ("'TThe rationale ... could easily be extended to situations where a substantive crime was in fact committed. The example of a kidnapper voluntarily returning his victim was raised. Such a renunciation certainly 'negatives dangerousness of character' and encourages 'actors to desist from pressing forward with their criminal designs.' ") (quoting MODEL PENAL CODE § 5.01 comment at $72-73$ (Tent. Draft No. $10,1960)$ ). 
liability for attempted larceny, because abandonment is not a matter of repentance for past conduct. Not liaving abandoned your attempt, you liave no abandonment defense, wliatever tlie evidence of later repentance.

Let us drop the term "repentance" and speak instead of the possibility of an abandonment defense to other crimes. As used witl attempt, "abandonment" refers to the future. When one attempts to commit a crime, one's conduct is directed to brimging about a prohibited state of affairs. One abandons an attempt by discontinuing the effort to brimg about that state of affairs, by giving up the criminal purpose or objective. Put shortly, a necessary condition for abandonment is a goal tlie effort to achieve whicl can be abandoned. Whetler one can abandon some otler crime as one can abandon an attempt thus depends on what that crime prohibits. One cannot, for instance, abandon a murder, because the crime does not specify a future state of affairs. In contrast, all furtlier intent crimes-crimes defined as "doing $B$ witli imtent to do $A$ "165_can be abandoned. If larceny is defined as "tak[mg] . . nnovable property of anotlier witl purpose to deprive him thereof," 166 one miglit abandon larceny by returning the stolen goods. Similarly, one nriglit abandon a possession crime requiring further intent, such as "possess[ing] any instrument of crime witl purpose to employ it criminally."167 Simple possession of narcotics, however, is not a further intent crime, and one does not abandon an effort to achieve a goal specified in the crime when one throws the narcotics away. But if narcotics possession is prohibited because of a future state of affairs to which it is thought to be related, then we inay say tliat simple possession too can be abandoned.

The first step in responding to the otler-crimes objection is thus to determine whetlier a particular crime can be abandoned. If it can, then the question is whether an argument for the abandonment defense to atteinpt is also an argument for an abandonment defense to that crime. So proponents of the arguments that Fletclier attacks might agree thia an abandonment defense will provide "an inducement to return stolen property" and that throwing narcotics away "indicates a cliange of cliaracter."168 They could then meet the objection by arguing that abandonment should be a defense not only to attempt, but also to larceny and narcotics possession.

I can now respond to the other-crimes objection on behalf of my own arguinent in support of the abandonment defense. According to

165. They may be called "ulterior intent" crimes. See Colvin, $A$ Theory of the Intoxication Defence, 59 CAN. B. Rev. 750, 757 (1981). This is a large category. See, eg., W. LAFAve \& A. ScorT, supra note 16, $\$$ 99, at 425; Dawkius, Attempting to Have in Possession, 5 OTAGo L. REv. $172,176-77$ (1981).

166. MODEl Penal CoDe $\S 223.2(1)$ (1980).

167. Model Penal CoDE $\S 5.06$ (1) (Official Draft and Explanatory Notes 1985).

168. G. FLETCHER, supra note 35 , § 3.3.8, at 186-87 (footnote omitted). 
that argument, the justification of attempt liability-upholding the substantive rules-does not justify prohibitimg abandoned attempts. Consequently, the argument applies to any crime im which conduct is prohibited in order to uphold substantive rules. This is probably the only justification for many further intent crimes, such as assault with intent to rob (or rape, kill, etc.) ${ }^{169}$ or, say, the federal offense of entering a bank with intent to commit a felony. ${ }^{170}$ For some further intent crimes, however, there may be another justification. If so, my argument does not apply to them. ${ }^{171}$

But I am not concerned to claim that my argument directly applies to this or that crime. Even if, on my argument, there is no abandonment defense to burglary, ${ }^{172}$ for example, it does not follow that abandonment should not be a defense to burglary. That depends on whether the rationale that justifies hability for unabandoned burglaries similarly justifies hability for abandoned burglaries. My argument for the abandonment defense to attempt is an application of a general form of argument. From that perspective the valuable point in the other-crimes objection is simply this: it invites our attention to problems of temporal individuation that arise witl claims for the recognition of defenses to otlier crimes because of other post-crime conduct or events.

\section{IV}

\section{Problems of TEMPORAL INDIVIDUATION}

In making criminalization decisions, we necessarily decide how we will individuate prohibited states of affairs in time. Thus we should always be prepared, in virtue of post-crime conduct or events, to alter the temporal dimensions of liability. To resolve such problems of temporal individuation, we should use the general form of argument I have applied to the abandonment defense. As further support for this contention, I will first deal witl possible confusions concerning the analysis of such problems in terms of crimes and post-crime conduct or events. I will conclude with illustrative applications of this form of argument.

169. Cf. Model Penal CoDE art. 211 introductory note at 172 (1980) ("Crimes such as assault with intent to rape or assault with intent to murder are discontinued on the ground that they really amount to no more than an attempt to commit the object offense.").

170. 18 U.S.C. $\$ 2113$ (a) (1982).

171. My argument does not apply to larceny, for example, because the future state of affairs specified in the crime is not criminally prohibited, and thus there is no substantive rule to uphold.

172. Although burglary may be viewed (in its modern definitions) as merely "a rather unique type of attempt law," W. LAFAVE \& A. ScoTT, supra note $16, \S 96$, at 715 , it may also be viewed (in a suitably restricted definition) as prohibiting "criminal invasion of premises under circumstances likely to terrorize occupants," MODEL PENAL CODE art. 221 introductory note at 59 (1980). On the latter view, my argument is inapplicable. 


\section{A. Post-Crime Conduct or Events}

Since we have different reasons for different criminal prohibitions, and since there are many types of post-crime conduct or events, application of iny form of argument to problems of temporal individuation will lead us to take such conduct or events into account in some, but not all, criminalization decisions. Professor Kelman, however, claims that this selectivity has no rational warrant.

Kelman introduces the expression "time-framing" with reference to "the way we view disruptive incidents." 173 In his terminology, we use a "narrow" time frame when we focus on the "criminal incident" (that is, the crime) and a "broad" time frame when we focus as well on conduct or events that follow commission of the crime. ${ }^{174}$ His example of the latter is the abandonment defense. Taking as given the crime of attempt without the defense, he says that we can make the decision to recognize the defense only after we have broadened the time frame to permit inclusion of an event that follows the criminal incident. ${ }^{175}$ Broad time-framing is thus, he thinks, necessarily presupposed in all criminalization decisions based on post-crime conduct or events. But the process of time-framing, according to Kelman, is nonrational. So these decisions are rationally unwarranted. ${ }^{176}$

A counterexample will show the futility of Kelman's claim. Consider its apphication to the temporal imdividuation of homicide. The criminal incident is given as the killing of the victim. But suppose we amend the penal code to eliminate the result from crimes defined by the occurrence of a specified result, so that homicide no longer requires the victim's death. Thus, acting with intent to kill may count as murder, and acting recklessly may count as manslaughter, whether or not the victim dies. The criminal incident is now given as engaging in the prohibited conduct. But then we decide to reainend the homicide provisions to take into account the post-crime event of the victim's death. To do that, we have to broaden the time frame beyond the criminal incident, for engaging in the prohibited conduct can be homicide only if it is followed by the victimi's death. With this change it becomes a defense to murder and inanslaughter that the victim did not die. ${ }^{177}$ Yet the decision to define

173. Kelman, supra note 85 , at 593 .

174. Id. at 594.

175. Id. at 611 .

176. Id. at $592-94,611$.

177. Here is Kelman's description of the use of a broad time frame in the abandonment defense:

The basic decision to allow [an] abandonment defense follows a wide time-framed interpretive construction. The defendant has already committed some act which, if interrupted by external forces, would constitute . . . an attempt . . . . Yet we judge the act innocent [i.e., not attempt] because of the defendant's subsequent failure to consummate the harm. 
homicide to include the victim's death (and therefore to recognize this defense), so long as we have reason for it, is not rationally unwarranted. The main confusion in Kelman's claim, then, is the idea that we engage in an mdependent and logically prior process of time-framing that could be somehow incompatible with the rationality of our criminalization decisions. ${ }^{178}$

In deciding how prohibited states of affairs should be temporally individuated, we consider reasons for recognizing defenses that refer to conduct or events that might later occur and that are thought to bear on our decisions. That such defenses require a broad time frame is of no significance. We will reject, for example, the claim that the defendant's post-crime conduct of doing cartwheels should be a defense to attempt, because no good reason supports recognition of a cartwheel defense. On the other hand, suppose we believe that the defendant's post-crime abandonment should be a defense because otherwise those who did not try to break substantive rules would be unjustifiably subject to attempt liability. If that is good reason for recognizing the abandonment defense, it is, unavoidably, good reason for broadening the time frame. Far from having any logical priority, a broad time frame is merely an inseparable accompaniment of arguments and disputes about the relevance of postcrime conduct or events to particular criminalization decisions.

Nor should we imistakenly assume tliat "post-crime" implies that crimes or criminal incidents are to be taken as given. If, in drafting a new penal code, you propose to prohibit engaging in reckless conduct, I may argue that liability should be imposed only when the conduct causes injury. But perhaps I offer my proposal first, and you argue that liability should be imposed even when the conduct does not cause injury. In the former instance, we are disputing about a post-crime event; in the latter, we are not. Yet our dispute is the same under either proposal, and it would still be the same if, rather than writing on a clean slate, we were decidimg whether to change the rule we already had. What we label as

Id. at 611 (footnote omitted). We could describe the defense to homicide discussed in the text in parallel fashion:

The basic decision to allow a defense of the nonoccurrence of death follows a wide timeframed interpretive construction. The defendant has already committed some act which, if the victim's death resulted, would constitute a homicide. Yet we judge the act innocent (i.e., not homicide) because of the subsequent failure of the harm to occur.

178. Kelman's claim is also defective in other ways. To support his view that the decision to allow the abandonment defense is rationally unwarranted, he makes the following assertion: "Although many reasons for this widened time frame have been offered, none overcomes the fundamentally nonrational, interpretive aspect of the initial broadening of focus." Id. But to say that none of the reasons for broadening the time frame overcomes the "nonrational . . broadening" is to assume rather than demonstrate that the broadening is nonrational. Moreover, supposing it is intelligible to say that reasons can overcome a nonrational broadening of the time frame, Kelman is not entitled to assert that the broadening is nonrational until be shows not just that many reasons fail, but that no reason could ever succeed. 
the "crime" and what we label as the "post-crime" conduct or event should serve to organize the analysis of a problem of temporal individuation. But the labels have nothing to do with the inerits (or the rationality) of the resulting criminalization decision.

On the inerits, our concern is that crimes be temporally individuated in ways that impose ouly justified liability. It follows, on my argument, thiat we should recognize the abandonment defense to attempt. But assuming that we should take into account the post-crime event of abandonment in the decision to prohibit atteinpts, it does not follow that we should also "admit[] evidence of post-criminal conduct (whetler remorse, restitution, condonation, or reform) into every trial."179 Whether we sliould define the teinporal dimensions of liability differently because of such post-crime conduct or events depends on tlieir relevance to our criminalization decisions and, therefore, on the justifying rationales of particular crimes. For purposes of illustration, I will apply iny general form of argument to these four post-crime events.

\section{B. Illustrative Applications of the Form of Argument}

Probleins of temporal individuation arise when post-crime conduct or events are claimed to be relevant to criminalization decisions. Examples include claims that abandonment sliould be a defense to conspiracy or solicitation, ${ }^{180}$ or to burglary; ${ }^{181}$ that disposal of the narcotics or the deadly weapon slould be a defense to illegal possession; ${ }^{182}$ thiat retraction of the false testimony sliould be a defense to perjury; ${ }^{183}$ and that immediate extinguishinent of the fire should be a defense to arson. ${ }^{184}$ Ratlier than actually resolve such problenns, however, I will sliow liow we sliould proceed in order to resolve thein. Thus, I will illustrate the general form

179. Id. at 612 .

180. Many jurisdictions provide for an abandonment defense to conspiracy and solicitation. See 1 P. Robinson, supra note 155, $\$ 81$ (c), at 354-57, $\$ 81$ (d), at 361-62; cf. TEX. PENAL Code ANN. $\S 17.05$ (Vernon Supp. 1986) (abandonment defense to engaging in organized criminal activity). Many others, however, do not. As with attempt, the traditional common law objection is that "the conspiracy offense is completed on agreement ... and that no subsequent events should serve to erase a previously committed crime." Note, Conspiracy: Statutory Reform Since the Model Penal Code, 75 Colum. L. REv. 1122, 1172 (1975) (footnote omitted); see Model PENAL CoDE $\$ 5.03$ comment at 143 (Tent. Draft No. 10, 1960). On the other hand, some jurisdictions with modern penal codes recognize the defense to solicitation or conspiracy, but not to attempt. See IowA CODE ANN. $\S 705.2$ (West 1979); KAN. STAT. ANN. § 21-3303(c) (Supp. 1983); Mo. ANN. STAT. § 564.016(5) (Vernon 1979); Neb. REV. STAT. § 28-203 (1979); N.M. STAT. ANN. § 30-28-3(B)(2) (1978).

181. See supra note 172 and accompanying text.

182. See supra note 167 and accompanying text.

183. See infra note 197.

184. In Germany, "active repentance" is a defense to arson, provided that "the perpetrator ... extingnish[es] the fire before any damage other than that resulting from the mere setting of the fire occurs." Oehler, supra note 115, at 700 (citing STGB art. 310 (W. Ger.)). 
of argument with claims for defenses based on less specific post-crime events.

\section{Remorse}

Remorse may occur after the commission of any crime, but we expect it most when someone is killed. Indeed, in many homicides the defendant and the victim were family members, friends, or acquaintances, and in such cases remorse may well be a common occurrence. Suppose, then, that the question is raised whether the defendant's postcrime remorse should be a defense to murder. If we do not recognize the remorse defense, killing another person is murder whether or not followed by remorse. If we do recognize the defense, however, there are two kinds of killing: unremorseful killing, which is murder, and remorseful killing, which is not. To decide whether to recognize the defense, we must decide whether there is good reason for prohibiting remorseful killings.

We proceed as follows. First, we determine whether we have good reason for prohibiting unreinorseful killings. Obviously we do, so the task here is to articulate the rationale that justifies imposing that liability. Second, we ask whether our rationale similarly justifies liability for reinorseful killings. Now we may of course have inultiple reasons, of varying strengths, for prohibiting unremorseful kilhings, and they may conflict when apphed to remorseful killings. We will thus have to make an overall judgment whether the justification of hability for unremorseful killings gives us good reason for prohibiting remorseful killings. If we conclude that it does not, or if our conclusion is uncertain, we then inquire into possible derivative reasons for prohibiting remorseful killmgs. It is at this stage that considerations such as difficulties of proof and public perceptions of the defense come in. ${ }^{185}$ If neither the rationale of hability for unremorseful killings, nor the derivative reasons, nor both in combination justify the prohibition of remorseful killmgs, then we should recognize the remorse defense to murder.

I set out the form of the arguinent in full, but I do not intend to explore the precise rationale for the prohibition of murder. If our rationale strongly emphasized what killing does to the killer's soul, then perhaps remorse would be of paramount significance. Otherwise, much as we value reinorse in these circuinstances, we are unlikely to decide that hability for reinorseful killings is unjustified.

\section{Restitution}

Restitution is sometimes mentioned as a relevant post-crine

185. See supra text accompanying notes $153-60$. 
event. ${ }^{186}$ Thus Professor Fletcher speaks of "a thief [who] returned the goods that he stole," 187 and Professor Kelman notes that "[a]n embezzler .. . may return money to victims unaware of their loss." 188 Whether such defendants should have a defense may depend on the type of theft. The rationale of embezzlement may differ from the rationale of larceny, and so too, therefore, may the import of the property's being returned to victims who are unaware of the loss.

Consider larceny. To decide whether restitution should be a defense, we begin by dividing the crime into two kinds: larceny where the property is taken and not returned (nonrestitutive larceny), and larceny where the property is taken and returned (restitutive larceny). We then ask whether the justification of hability for nonrestitutive larcemies justifies hability for restitutive larcemes as well. Originally " $[t]$ he goal was inore to prevent breaches of the peace than losses of property," which would seem to be good reason for prohibiting restitutive larcemies. But "[a]s the common law developed, protection of property also became an important goal."190 If that is a substantial part of the justification today, then the question is more complex. In particular, the extent to which a restitution defense would encourage the return of stolen property becomes an important consideration. If we think that knowledge of the defense will be sufficiently widespread, we might conclude that recogintion of the defense will increase the protection of property. Then the reasons for prohibiting nonrestitutive larcemies conflict when applied to restitutive larceines. The relative weight we assign these reasons will determine our overall judginent whether we have good reason for prohibiting restitutive larcenies.

Restitution is a stronger candidate for a defense in bad check statutes. The crime (which is essentially the crime of false pretenses) is directed at the conduct of those who fraudulently issue worthless checks. ${ }^{191}$ The rationale for prohibiting such conduct is "partly to safeguard public confidence in the check as a medium of payment in commercial activity" and partly to "protect[] property owners against

186. Restitution is not ordinarily a defense. See, e.g., Lacy v. State, 176 Ind. App. 428, 375 N.E.2d 1133 (1978) (return of property no defense to robbery); Freeman v. Meijer, 95 Mich. App. 475, 291 N.W.2d 87 (1980) (no defense where shoplifter put items back); State v. Bretz, 185 Mont. 253, 296, 605 P.2d 974, 998-99 (1979) (restitution no defense to larceny by bailee), cert denied, 444 U.S. 994 (1979); State v. Burnham, 19 Wash. App. 442, 446, 576 P.2d 917, $918-19$ (1978) (defendant returned property, but "however laudable repentance may be, a later change of heart is no defense to a completed theft"); $c f$. Potter v. State, 511 P.2d 1120, 1124 (Okla. Crim. App. 1973) (abandonment no defense to robbery).

187. G. FLETCHER, supra note 35 , § 3.3.8, at 186 .

188. Kelman, supra note 85 , at 612 (footnote omitted).

189. Bell v. United States, 462 U.S. 356, 358 (1983).

190. Id. at 359.

191. See R. Perkins \& R. Boyce, Criminal Law 384-88 (3d ed. 1982). 
property loss."192 Although the first reason suggests prohibiting both restitutive and nonrestitutive bad checks, the second reason might weigh more heavily in this context. The statute could provide, as some do, that the crime is committed unless the writer pays the check withm so many days of receivmg notice of dishonor. ${ }^{193}$ With this notification requirement, the defense should furnish a powerful imcentive for one to redeem one's checks. Assuming that is so, we will probably decide that we do not have good reason for prohibiting restitutive bad checks. ${ }^{194}$

The traditional objection to the abandonment defense to attemptthat attempt is a "completed" crime ${ }^{195}$ _ has a counterpart to the restitution defense. In a Wyoming case upholding the constitutionahity of a bad check statute with a restitution provision, the dissenter complained that the crime was complete and "should not become a nullity because thereafter the check writer makes [the check] good."196 This objection is as question begging with restitution as it is with abandoninent. If the defendant properly makes restitution, then the crime was never completed and there is nothing to nullify. ${ }^{197}$

192. W. LAFAVE \& A. SCOTT, supra note $16, \S 92$, at 680 (footnote omitted).

193. See WYO. STAT. $\S 6-3-702$ (1983) (5 days). It is more common to provide that failure to pay within a specified period is prima facie evidence of the requisite mental state. E.g., W1S. STAT. ANN. $\S 943.24(3)$ (b) (West 1982) (5 days); see W. LAFAVE \& A. ScoTT, supra note 16, $\S 92$, at 680. This leads to the same result in practice: "those making restitution escape prosecution while those who do not make restitution are charged." Locklear v. State, 86 Wis. 2d 603, 613, 273 N.W.2d 334, 338 (1979). There are similar embezzlement statutes, "making the refusal of an officer, clerk, agent or other, to hand over on demand money or property in his care, prima-facie evidence of embezzlement." R. PERKINS \& R. BOYCE, supra note 191, at 1090 (footnote omitted).

194. The primary challenge to bad check statutes providing for a restitution defense is on equal protection grounds. Two such North Dakota statutes have been held to discriminate unconstitutionally against the indigent. State v. Fischer, 349 N.W.2d 16 (N.D. 1984); State v. Carpenter, 301 N.W.2d 106 (N.D. 1980). A Mississippi statute, under which "payment . . . within ten days after the receipt of the notice, [is] an absolute bar to further prosecution," was held to violate the state constitutional prohibition on imprisonment for debt. State v. Johnson, 163 Miss. 521, 529-30, 141 So. 338, 340 (1932); accord Burnam v. Commonwealth, $228 \mathrm{Ky}$. 410, 15 S.W.2d 256 (1929). Those statutes, however, did not require intent to defraud. In State v. Laude, 654 P.2d 1223 (Wyo. 1982), where the statute required such intent, the court rejected an equal protection challenge: "The grace period thus makes restitution available to all persons on a uniform basis and more rationally fair for all." Id. at 1227; cf. Locklear v. State, 86 Wis. 2d 603, 273 N.W.2d 334 (1979) (upholding constitutionality of bad check statute's prima facie evidence provision).

195. See supra note 1 and accompanying text.

196. State v. Laude, 654 P.2d 1223, 1230 (Wyo. 1982) (Brown, J., dissenting). The majority correctly asserted that "the ten-day redemption provision . . . simply refiects the legislature's intent to allow, in the definition of the crime, an opportunity for an otherwise guilty individual to have a change of heart and redeem his "bad check." "Id. at 1229 n.6.

197. Consider also the crime of perjury and the post-crime event of retraction. The traditional view is that "perjury cannot be purged," Kimbrell, Crimes Against the Public, 38 MO. L. REV. 571, 586 n. 100 (1973), because "the crime is complete when a witness's statement has once been made," United States v. Norris, 300 U.S. 564, 574 (1937); see Note, The Criminal Code Reform Bill of 1978 and the Peril of False Statements, 47 GEO. WASH. L. REV. 573, 582 (1979). Nevertheless, the Model Penal Code drafters proposed a retraction defense in order to provide an "incentive to correct falsehoods." MODEL PENAL CODE $§ 208.20$ comment at 129 (Tent. Draft No. 6, 1957). Federal 


\section{Condonation}

The post-crime event of condonation-the forgiveness of a crime by the victim-imight be the basis of a defense to certain crimes. In soine jurisdictions, for exainple, condonation by inarriage prevents prosecution for seduction. ${ }^{198}$ Similarly, prosecution for adultery may require a coinplaint by the victim, effectively allowing the aggrieved spouse to condone the crime. ${ }^{199}$ In addition, a number of states have misdemeanor-compromise statutes providing for dismissal of the prosecution if the injured party condones the crime by acknowledging $\mathrm{i}$ court that satisfaction for the injury has been received. 200

Let us take as an illustration a more serious crime. Consider the claim that condonation should be a defense to rape. ${ }^{201}$ We divide the crime into two kinds, uncondoned rape and condoned rape, and we ask whether the rationale for prohibiting the first kind gives us good reason for prohibiting the second. If it does, then in relation to the post-crime event of condonation, the crime of rape is temporally individuated in a way that does not impose unjustified hability.

This determination, however, does not mean that we are bound to reject the condonation defense. Although the defense does not follow froin the justification of rape liability, there might be soine other reason for recognizing it. Indeed, as ordinarily understood, a condonation defense does not reflect a conclusion that criminal hability is unjustified. It belongs, rather, in the category of "[n]onexculpatory defenses," as they

law and inany of the new state criminal codes have since included the defense. E.g., 18 U.S.C. $\S 1623$ (d) (1982); Ilinois Criminal Code of 1961, § 32-2(c), ILL. ANN. STAT. ch. 38, § 32-2(c) (Smith-Hurd 1982); IowA CodE ANN. $\$ 720.2$ (West 1979); N.H. REv. STAT. ANN. § 641:1 (II)(1974); Tex. Penal Code ANN. \$37.05 (Vernon 1974); see Model PeNal Code $\$ 241.1$ comment at $131 \mathrm{n} .98$ (1980) (citing statutes). If perjury liability is imposed to enhance "the ability of an investigating body to learn the truth," 1 WORKING PAPERS OF THE NATIONAL COMMISSION, supra note 156, at 666 , and if we believe that the defense is "a valuable aid in encouraging corrections of sworn mis[s]tatements," Israel, The Process of Penal Law Reform-A Look at the Proposed Michigan Revised Criminal Code, 14 WAYNE L. REv. 773, 808 n.200 (1968), perhaps because witnesses have the opportunity for second thoughts after their testimony and may get or have legal advice or otherwise become aware of the defense, then we will conclude that hability for retracted perjuries is unjustified.

198. E.g., Cal. Penal Code $\S 269$ (West 1970); see W. LAFAve \& A. ScotT, supra note 16, $\S 57$, at 411; R. PERKINS \& R. BOYCE, supra note 191, at 1089.

199. See W. LAFAVE \& A. SCOTT, supra note $16, \S 57$, at $411 ;$ R. PERKINS \& R. BoYCE, supra note 191, at 1090 .

200. E.g., AR1z. Rev. Stat. ANN. § 13-3981 (1978); Cal. Penal Code §§ 1377-1379 (West 1970); OR. REV. STAT. $\$ 135.705$ (1985); see W. LAFAVE \& A. ScoTT, supra note 16, $§ 57$, at 411.

201. The former Illinois statutory-rape provision barred prosecution if the accused and the victim subsequently married. ILL. ANN. STAT. ch. 38, $\S 490$ (1955) (repealed 1961). Courts traditionally have rejected the defense. See State v. Newcomer, 59 Kan. 668, 54 P. 685 (1898) (statutory rape); Comınonwealth v. Slattery, 147 Mass. 423, 18 N.E. 399 (1888) (rape); People v. Marrs, 125 Mich. 376, 84 N.W. 284 (1900) (assault with intent to rape); State v. Hartigan, 32 Vt. 607 (1860) (consent after atteinpted rape). 
have been called, which "arise where an important public policy . . . is protected or furthered by foregoing trial or conviction and punishment." 202 These defenses reflect decisions that even though liability is justified, there is nevertheless better reason for recognizing a defense. The provisions for a condonation defense to seduction and adultery, for example, appear to rest on the view "that conviction is unwise if the victim has otherwise obtained satisfaction, perhaps because the crime is in reality more private than public in nature."203 Assuming that liability for condoned rapes is justified, one would need to find some such overridmg reason to support the condonation defense to rape. Finding such a reason is, I suspect, an unlikely prospect.

\section{Reform}

The post-crime event of the defendant's reform can be relevant only to crimes whose rationale is that persons who commit them have criminal dispositions. So let us consider attempt again. Assume that the law recognizes the abandonment defense. That problem of temporal individuation has been resolved, and now we face an additional one. Should we also recognize a reform defense to attempt?

We divide unabandoned attempts into two kinds: those not followed by the defendant's reform (unreformed attempts) and those followed by the defendant's reform (reformed attempts). We then decide whether there is good reason for prohibiting reformed attempts. If we accept the Model Penal Code view that attempts are prohibited because attempters are dangerous persons, ${ }^{204}$ we may well conclude that the rationale of attempt liability does not justify liability for reformed attempts. If so, then unless derivative reasons are sufficient to justify liability, we will decide that the law should recognize the reform defense. If, however, we accept some other theory of attempt liability, we will conclude that there is good reason for prohibiting both reformed and unreformed attempts. In a problem of temporal individuation, the relevance of a post-crime event depends on the rationale of the crime.

202. 2 P. Robinson, supra note $155, \S 201$ (a), at 460 . Professor Robinson places in this category, inter alia, the defenses of diplomatic immunity, governmental immunity, and entrapment. See id. $\S \S 203,204,209$. Several such nonexculpatory defenses are based on post-crime conduct or events. See id. $\S 202(\mathrm{a})$-(b) (statute of limitations defense); id. $\S 205(\mathrm{~b})$, at 485-86 (defense of transactional immunity); id. $\S 206($ a), at $489, \S 206(d)$, at $492-95$ (defense of plea bargained immunity). Robinson does not, however, discuss a coudonation defense in his treatise.

203. W. LAFAvE \& A. SCOTr, supra note $16, \S 57$, at 411 . The same reason was given for the nineteenth-century forerunner of the current misdemeanor-compromise statutes. See THE COMM'RS on Practice and Pleadings, Report of the Code of Criminal Procedure of the State OF NEW YORK 339 (1850).

204. See supra text accompanying notes $17-28$. 


\section{CONCLUSION}

The temporal individuation of criminal prohibitions requires inaking choices. The general form of argument applied in this Article to support the abandonment defense, and illustrated with the exainples in Part IV, will ensure that we can justify those choices. Whenever it is claimed that we have ignored some post-crime conduct or event that bears on a criminalization decision, we must reexamine our reasons for temporally defining the crime im the way that we do. Questions whether to recognize proposed defenses because of such conduct or events are simply questions of properly defining the states of affairs that we can justifiably prohibit. 
